\title{
Modulation of EndMT by Hydrogen Sulfide in the Prevention of Cardiovascular Fibrosis
}

\author{
Lara Testai $^{1,2, *(\mathbb{D})}$, Vincenzo Brancaleone ${ }^{3}(\mathbb{D})$, Lorenzo Flori ${ }^{1}$, Rosangela Montanaro ${ }^{3}$ and Vincenzo Calderone ${ }^{1,2}$ \\ 1 Department of Pharmacy, University of Pisa, 56126 Pisa, Italy; lorenzo.flori@phd.unipi.it (L.F.); \\ vincenzo.calderone@unipi.it (V.C.) \\ 2 Interdepartmental Center of Ageing, University of Pisa, 56126 Pisa, Italy \\ 3 Department of Science, University of Basilicata, 85100 Potenza, Italy; vincenzo.brancaleone@unibas.it (V.B.); \\ rosangela.montanaro@unibas.it (R.M.) \\ * Correspondence: lara.testai@unipi.it
}

Citation: Testai, L.; Brancaleone, V.; Flori, L.; Montanaro, R.; Calderone, V Modulation of EndMT by Hydrogen Sulfide in the Prevention of Cardiovascular Fibrosis. Antioxidants 2021, 10, 910. https://doi.org/ $10.3390 /$ antiox 10060910

Academic Editor: Fabio Galvano

Received: 15 April 2021

Accepted: 1 June 2021

Published: 3 June 2021

Publisher's Note: MDPI stays neutral with regard to jurisdictional claims in published maps and institutional affiliations.

Copyright: (c) 2021 by the authors. Licensee MDPI, Basel, Switzerland. This article is an open access article distributed under the terms and conditions of the Creative Commons Attribution (CC BY) license (https:// creativecommons.org/licenses/by/ $4.0 /)$.

\begin{abstract}
Endothelial mesenchymal transition (EndMT) has been described as a fundamental process during embryogenesis; however, it can occur also in adult age, underlying pathological events, including fibrosis. Indeed, during EndMT, the endothelial cells lose their specific markers, such as vascular endothelial cadherin (VE-cadherin), and acquire a mesenchymal phenotype, expressing specific products, such as $\alpha$-smooth muscle actin ( $\alpha$-SMA) and type I collagen; moreover, the integrity of the endothelium is disrupted, and cells show a migratory, invasive and proliferative phenotype. Several stimuli can trigger this transition, but transforming growth factor (TGF- $\beta 1$ ) is considered the most relevant. EndMT can proceed in a canonical smad-dependent or non-canonical smadindependent manner and ultimately regulate gene expression of pro-fibrotic machinery. These events lead to endothelial dysfunction and atherosclerosis at the vascular level as well as myocardial hypertrophy and fibrosis. Indeed, EndMT is the mechanism which promotes the progression of cardiovascular disorders following hypertension, diabetes, heart failure and also ageing. In this scenario, hydrogen sulfide $\left(\mathrm{H}_{2} \mathrm{~S}\right)$ has been widely described for its preventive properties, but its role in EndMT is poorly investigated. This review is focused on the evaluation of the putative role of $\mathrm{H}_{2} \mathrm{~S}$ in the EndMT process.
\end{abstract}

Keywords: gasotransmitter; endothelial mesenchymal transition; fibroblast phenotype; cardiovascular diseases; TGF- $\beta$

\section{Introduction}

Endothelial mesenchymal transition (EndMT) is a complex biological process in which endothelial cells lose their specific markers, such as vascular endothelial cadherin (VE-cadherin), and acquire a mesenchymal or myofibroblastic phenotype, expressing specific products, such as $\alpha$-smooth muscle actin ( $\alpha$-SMA) and type I collagen [1]. From a histological point of view, during EndMT, the integrity of the endothelium is disrupted, manifesting a migratory, invasive and proliferative phenotype. Vascular endothelium can be viewed as a specialized form of epithelial tissue. Consistently, EndMT shares many molecular mechanisms with the best-known epithelial mesenchymal transition (EMT), a physiological reversible process, first described in the 1960s in chick embryos by Hay and today known to be required for normal embryonic patterning and organs' formation [1].

Kovacic et al. first reported that EndMT represents a crucial step in the formation of septa and valves in mammalian hearts, during cardiogenesis; indeed, anomalous EndMT results in septal defects and valve abnormalities [2]. Of note, recent evidence suggests that this phenomenon also has an important role in various adult conditions, including fibrosis, wound repair and inflammation [2,3].

This theory has been formulated on the basis of the first pioneer studies, in which adult bovine endothelial cells with an endothelial-specific phenotype could differentiate into 
smooth muscle cells. The start of trans-differentiation was correlated with the disruption of cell-cell contacts and was induced by transforming growth factor (TGF- $\beta 1$ ). This suggested that mature bovine large-vessel endothelial cells were able to acquire a smooth muscle phenotype [4].

However, the EndMT must be seen as a dynamic and reversible process, in which mesenchymal phenotype, under specific stimuli, can recover the endothelial feature. In this regard, Ubil and colleagues described a critical contribution of mesenchymal-endothelial transition (MEndT) in post-infarct cardiac neovascularization. They demonstrated that, in ex vivo and in vivo models, cardiac fibroblasts could adopt endothelial cell fate after stimulation of the p53 pathway, leading to angiogenesis and promoting the reparation of injured myocardium; vice versa, treatment with TGF- $\beta$ repressed them $[5,6]$.

\section{Molecular Mechanisms Underlying the EndMT}

A complex network of gene activation and repression programs are required for the initiation, execution and maintenance of switching phenotypes. In particular, EndMT occurs under several types of stimuli, including fibroblast growth factor (FGF), interferon gamma (IFN- $\gamma$ ) and metabolic factors, such as oxidized low-density lipoproteins (oxLDL), highdensity lipoproteins (HDL) and high glucose (HG) levels. However, TGF- $\beta$ is considered the prominent regulator of EndMT. Then, EndMT proceeds through several smaddependent and smad-independent signaling pathways, including Notch, Wnt and PI3K/Akt pathways. These engage special transcription factors (snail, slug, twist and ZAB), which are responsible for repression of the endothelial phenotype as well as progression of the transition process, characterized by expression of mesenchymal markers [7-11].

\subsection{TGF- $\beta$-Dependent EndMT}

TGF- $\beta$ and bone morphogenetic protein (BMP) belong to the TGF- $\beta$ superfamily [12]. Analyzing the phenotypes of mice deficient in components of the TGF- $\beta$ signaling cascade, the importance of the TGF- $\beta$ signaling pathways in the spatial and temporal regulation of heart and blood vessel morphogenesis, as well as cardiovascular homeostasis, is evident. For example, TGF- $\beta 1$-deficient mice show decreased age-associated myocardial fibrosis and improved cardiac compliance. Conversely, mice with TGF- $\beta 1$ overexpression have significant ventricular fibrosis, with an increase of cardiac fibroblasts. Accordingly, treatment with NP-40208, an antagonist of the TGF- $\beta$ receptor, attenuates myocardial fibrosis in mice [13]. Therefore, today, therapeutic interventions focused on normalizing perturbed TGF- $\beta$ signaling are an emerging area of intense research.

Three isoforms of TGF- $\beta$ have been described. TGF- $\beta 1$, the most commonly studied in the context of pathological EndMT, intervenes, regulating the atrioventricular canal $(\mathrm{AVC})$ in mice during morphogenesis [14]. TGF- $\beta 2$ is the most important in developmental EndMT. For example, it seems to be involved in endocardial cushion formation, as observed by using TGF- $\beta$ knockout embryos and cultured AVC explanted from TGF- $\beta$ knockout mice [9,15-18]. Finally, the effects of the TGF- $\beta 3$ isoform on EndMT are relatively unknown, during development as well as pathological conditions [19].

TGF- $\beta$ is a dimeric cytokine produced from various cells in an inactive form, in which the amino-terminal part is non-covalently associated with the mature carboxy terminal peptide. Upon proteolytic cleavage, the bioactive TGF- $\beta$ is released and can stimulate specific serine/threonine receptors (TGF- $\beta$ Rs) $[20,21]$.

Although the exact stoichiometry in the signaling complex is not known, in response to interaction of TGF- $\beta$ R type II with TGF- $\beta$, it dimerizes with the TGF- $\beta$ R type I (also termed activin receptor-like kinase, ALK), phosphorylates and triggers the internalization of the TGF- $\beta$-receptor complex. EndMT may proceed via both canonical smad-dependent and non-canonical smad-independent pathways. The canonical smad-dependent pathway requires the phosphorylation of smad 2 and 3 and their binding with the cytosolic smad4, to obtain a heterotrimer complex, that translocates into the nucleus, where it initiates the transition of endothelial cells. Antagonists of smad3 almost completely inhibit EndMT and 
fibrosis. Conversely, the activation of smad3 promotes fibrosis in a murine model [22-24]. Then, the transcription factors slug and snail repress endothelial markers (VE-cadherin and CD31), driving the cells towards the mesenchymal transition and fibrotic cardiovascular diseases. The TGF- $\beta$ /smad/snail/slug pathway is central; indeed, an inhibition of snail/slug reduces EndMT as well as the occurrence of cardiovascular diseases [25].

TGF- $\beta$ also activates the smad-independent signaling cascade, involving the engagement of several downstream kinases, such as mitogen-activated protein kinase (MAPK)/ extracellular-signal-regulated kinase (ERK), phosphoinositide 3-kinase (PI3K), Rho-like GTPase and p38 MAPK $[26,27]$. Akt is also found downstream of the TGF- $\beta$ signaling pathway and is activated in a RhoA-dependent manner. Furthermore, an inhibition of Akt reduces smad 2 phosphorylation and transcription. Finally, GSK- $3 \beta$ inhibits pro-fibrotic TGF- $\beta$ signaling via interaction with smad3 [28].

\subsection{TGF- $\beta$-Independent EndMT}

Several BMPs and their receptors (BMPRs) are also critical factors required for EndMT, and during embryogenesis they contribute to valve formation and cardiac septation $[29,30]$. The Notch pathway is also important during physiological cardiac development; indeed, mutations at this level are associated with defective valve formation [31], and the inhibition of Notch1 is associated with decreased EndMT and cardiac fibrosis [32].

Interestingly, Wnt signaling activation occurs upon cardiac injury and can start EndMT in the epicardium and contribute to generating cardiac fibrosis. In particular, $\beta$-catenin, the downstream effector, is stabilized and translocates into the nucleus, where it induces the transcription factor twist [33]. On the contrary, the disruption of Wnt signaling in epicardial cells decreases epicardial expansion as well as EMT and results in cardiac dysfunction and ventricular dilatation $[34,35]$.

Inflammatory cytokines, such as tumor necrosis factor- $\alpha$ (TNF- $\alpha$ ), interleukin- $1 \beta$ (IL$1 \beta$ ) and interleukin- 6 (IL-6), may be triggers of TGF- $\beta$-driven EndMT, through the nuclear factor- $\mathrm{kB}$ (NF-kB) pathway [36]. Moreover, the vasoactive peptide endothelin-1 (ET-1) has been found to promote cardiac fibrosis and heart failure in diabetic hearts through stimulation of EndMT. In particular, studies on human endothelial cells have demonstrated that ET- 1 is able to increase TGF- $\beta$-induced EndMT and that these effects involve the smad pathway [37,38].

Other cytokines may act as stimuli for EndMT, including IFN- $\gamma$, that acts through the Janus kinase (JAK)/signal transducer and activator of transcription (STAT) pathway, following the snail-dependent pathway [39]. FGF has been proposed as a gatekeeper of partial EndMT, since reduction of FGF signaling in mice represses TGF- $\beta$ signaling [40].

$\mathrm{PI} 3 \mathrm{~K} /$ Akt signaling has also been found to be involved in fibrosis in mice. It is associated with an increased expression of MMP9 at the vascular level and recruits the transcription factor ZEB [41].

Illigens and colleagues showed that exogenous administration of vascular endothelial growth factor (VEGF) contributed to preservation of myocardial systolic and diastolic function, preventing apoptosis. Moreover, a reduced extracellular matrix (ECM) deposition and then anti-fibrotic effects, through negative modulation of the TGF- $\beta$ /smad-dependent pathway, were reported [42].

Several studies have demonstrated that metabolic disorders, such as diabetes and dyslipidemia, are highly associated with the development of cardiovascular diseases, and EndMT is emerging as a further mechanism involved. In this regard, high levels of HDL show anti-fibrotic effects through the blockage of the TGF- $\beta$ /smad/slug/ZEB signaling pathway; conversely, HG conditions have been demonstrated to induce EndMT by means of the Akt/PI3K/NF-kB pathway and are associated to fibrosis in diabetic patients [43,44]. Likewise, Tang et al. demonstrated endothelial cell transition in streptozotocin (STZ)induced diabetes in mice and the involvement of the TGF- $\beta$ /smad/snail pathway [45]. In this regard, Mishra et al. observed that AMP-activated protein kinase (AMPK), a key modulator of cardiometabolic homeostasis, inhibited TGF- $\beta$-induced smad3-dependent 
transcription. This hypothesis has been strengthened by using AMPK $\alpha$ knockout mice, in which fibrosis was promoted and cardiac function was compromised [46].

Promotion of EndMT may be considered as a further possible mechanism of Angiotensin II (AngII)-mediated endothelial dysfunction, since the treatment with irbesartan attenuated it and slowed atherosclerosis in type II diabetes mellitus patients [47].

Epigenetic modifications can also participate in EndMT and play important roles in cardiovascular conditions, where DNA methylation, histone modifications and RNA interference are recognized as the most involved. For example, microRNAs, such as miRNA-125b, Let-7c, Let-7g, miRNA-21, miRNA-30b and miRNA-195, seem to promote profibrotic processes and are at the basis of pathogenesis of atherosclerosis, cardiac fibrosis and heart failure. Overexpression of miRNA-126, miRNA-483 and miRNA-155 has been associated to abrogation of the TGF- $\beta$ /smad pathway and to protective effects [48].

Furthermore, TGF- $\beta 1$ treatment in human coronary endothelial cells resulted in aberrant promoter methylation and thereby reduced gene expression of RASAL1 (RAS protein activator-like 1), which contributed to EndMT. Indeed, an aberrant promoter methylation of RASAL1 was also observed in an experimental murine model of cardiac fibrosis and in end-stage heart failure patients [48].

Interactions amongst these pathways increase the complexity of the process, since they all converge and induce the expression of transcription factors, such as snail, slug and twist, and ultimately modulate EndMT (Figure 1).

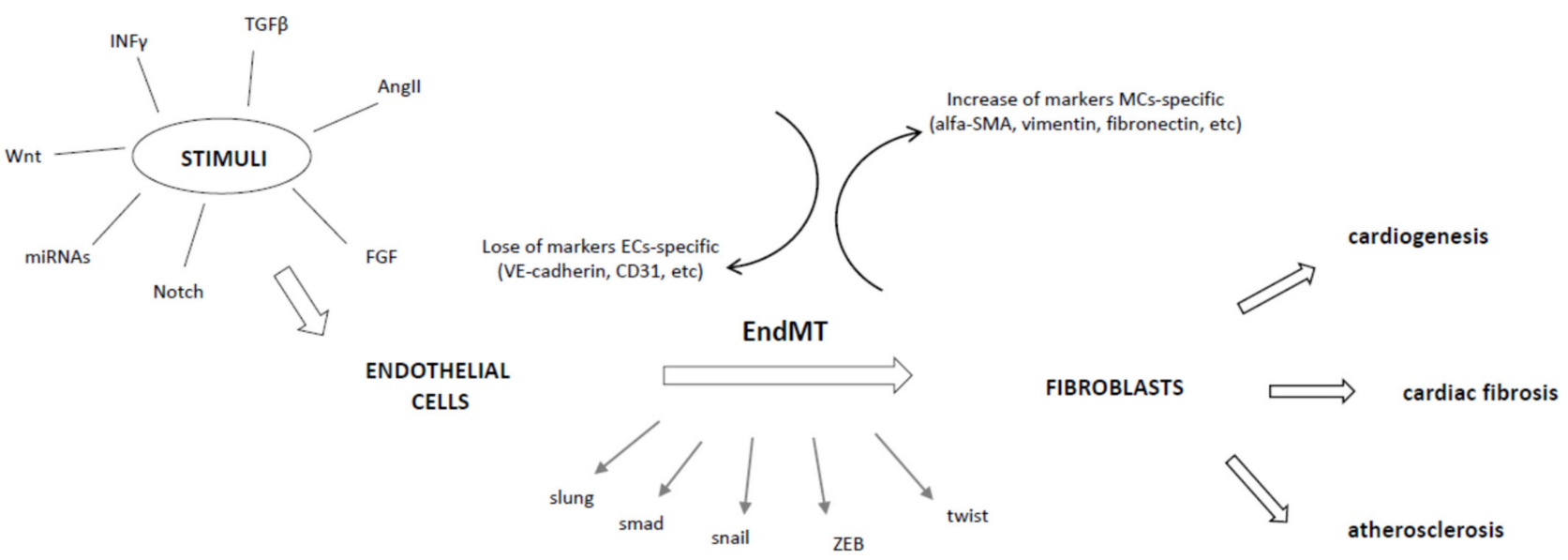

Figure 1. Schematic representation of molecular mechanisms underlying the EndMT phenomenon.

\section{EndMT: Implications in Cardiovascular Fibrosis}

Fibrosis is a complex process, in which tissue repair after damage becomes excessive and out of control, resulting in excessive formation of fibrous connective tissue. It can affect any tissue and cause organ dysfunction in different pathologies, such as heart disease, interstitial lung disease, liver cirrhosis, progressive systemic sclerosis and diabetic nephropathy [49].

Deposition of fibrotic scar tissue in the heart is typical after myocardial infarction in the post-ischemic stage, and in vessels of hypertensive subjects, it represents the way through which atherosclerosis develops. Other conditions can also induce and promote fibrotic processes in heart tissue, such as hypertensive cardiomyopathy, diabetic hypertrophic cardiomyopathy, idiopathic dilated cardiomyopathy and also physiological ageing [50,51].

\subsection{EndMT and Vascular Fibrosis}

Vascular fibrosis is associated with many diseases and their pathological progression, including atherosclerosis, which is one of the primary causes of the development of cardiovascular diseases. Indeed, atherosclerosis is characterized by accumulation of ECM proteins, primarily collagen and fibronectin, in the vascular media, contributing to 
structural vascular remodeling, proliferation of vascular smooth muscle cells and inhibition of matrix degradation, and is responsible for the thickness of the wall of arteries and formation of plaques [52]. Endothelial dysfunction is a critical event in the development of atherosclerosis; indeed, in physiological conditions, the endothelium is a monolayer squamous epithelium located in the luminal surface of the blood vessels and is a major regulator of vascular homeostasis. In particular, by the production of nitric oxide (NO), it preserves structural and functional integrity of the vessels. Reactive oxygen species (ROS) production is a major atherosclerotic risk factor that promotes NF-kB signaling and then inflammation. Proinflammatory cytokines contribute to increase the atherosclerotic region, through arterial plaque formation and additional cell apoptosis, leading to lipids' expulsion into adjacent plaque areas [53].

Interestingly, plaque formation during atherosclerosis has been associated with the accumulation of mesenchymal cells in the arterial intima, deriving from transition of endothelial cells. It is noteworthy that, in plaques of murine atherogenic models and in humans, endothelial and mesenchymal markers have been found, demonstrating the presence of a transitioning state of EndMT. Recently, it has been suggested that mesenchymal cells advance the progression of atherosclerosis, since they secrete proinflammatory molecules and synthetize ECM proteins and metalloproteases (MMPs), which facilitate plaque build-up and regulate plaque stability [54]. Interestingly, in endothelial cells, TGF- $\beta$ predominantly binds ALK-1, promoting smad1 and smad5, and contributes to regulation of vascular homeostasis, cell proliferation and angiogenesis; in contrast, when TGF- $\beta$ binds ALK5, it induces the activation of smad2 and smad3, which inhibit cell proliferation and facilitate EndMT $[55,56]$. Besides canonical TGF- $\beta$ signaling, TGF- $\beta$ can induce EndMT in a non-canonical way, through the activation of kinase-driven signaling pathways and the downstream induction of the mesenchymal transcription factors [55].

Angiogenesis is a vascular remodeling process, promoted by VEGF and other factors that stimulate proliferation and migration of vascular endothelial cells to form new blood vessels. As previously described, TGF- $\beta$, beyond its role in physiological [57] and degenerative processes, has been recognized as one of the key factors inducing the expression of VEGF in endothelial cells via the ALK-5 pathway, thus creating a pro-angiogenic milieu for the tumor or for the EndMT [58]. Indeed, excessive sprouting is associated with the TGF/VEGF pathway. However, FGF signaling is involved in angiogenesis modulation and in the maintenance of vascular integrity and endothelial function. Crosstalk between FGF and TGF- $\beta$ exists. In this regard, recent studies show that FGF inhibition at the endothelial level is associated with TGF- $\beta$ activation [57].

Very interestingly, EndMT of the specialized brain endothelial cells, forming the bloodbrain barrier, has been described in different conditions of neuroinflammation and neurodegeneration, typical of central nervous system pathologies, such as multiple sclerosis [59].

\subsection{EndMT and Cardiac Diseases}

Cardiac fibrosis is a hallmark of the heart's pathological remodeling response to mechanical or biochemical stress. This process serves to maintain the structural integrity of the myocardium, but inevitably leads to reduced contractile capacity. Indeed, cardiac fibrosis is characterized by increased stiffness of the heart valves, due to excessive proliferation of cardiac fibroblasts, accumulation of myofibroblasts and to deposition of ECM in the cardiac muscle. In particular, the ECM is a highly durable and mechanically stable fiber-containing structure that serves as a scaffold for cells and can be useful for wound healing and tissue regeneration. Nevertheless, unlike cardiomyocytes, cardiac fibroblasts are unable to generate an action potential and are not excitable (although they are able to electrically couple with each other and with neighboring cardiomyocytes), causing impaired mechanicalelectrical coupling and arrhythmias [60]. On the other hand, impaired tissue function, myocardial dysfunction and ultimately heart failure are also observed [61].

Myocardial infarction is the most common cause of cardiac fibrosis. However, various other conditions, such as hypertension, diabetic hypertrophic cardiomyopathy, idio- 
pathic dilated cardiomyopathy and ageing, may be responsible for reparative mechanisms, addressed to the replacement of dead cardiomyocytes with a collagen-based scar.

Another pathological condition promoting myocardial fibrosis is diabetic cardiomyopathy (DCM); interestingly, about $75 \%$ of patients with unexplained idiopathic dilated cardiomyopathy are found to be diabetic [62]. Endoplasmic reticulum stress, mitochondrial dysfunction, sympathetic nervous system activation, excessive oxidative stress, increased inflammation and abnormal coronary microcirculation are characteristic symptoms. These pathophysiological changes result in fibrosis, hypertrophy, diastolic/systolic dysfunction and ultimately systolic heart failure. In particular, cardiac interstitial fibrosis is a major feature of DCM [63], which includes the overproduction and deposition of myocardial interstitial collagen, resulting in myocardial stiffness and cardiac dysfunction.

Another aspect that can greatly affect the cardiovascular system is ageing. Ageing causes a decreased production of $\mathrm{NO}$ and a process of generalized endothelial dysfunction at the vascular level. At the cardiac level, consequently, with the progress of ageing, compensatory mechanisms addressed at hypertrophy [64-68] cause an increase in the left ventricular wall, which in the long term worsens the overall cardiac performance, and also triggers fibrotic processes as a final manifestation. Along with the mechanical consequences, cardiac fibrosis can also slow down the propagation of the electrical impulse and affect heart rate, suggesting that ageing can also promote cardiac arrhythmias [53].

First, in 2007, Ziesberg et al. hypothesized that EndMT is a process at the basis of cardiac fibrosis. Indeed, they observed that under stimulation, adult human coronary endothelial cells trans-differentiated into fibroblasts, and bone marrow cells could contribute to the cardiac fibroblast population. Moreover, they hypothesized that TGF- $\beta 1 / \mathrm{smad}$ was the signaling pathway through which EndMT developed. In fact, the treatment with rhBMP-7, a TGF- $\beta$ antagonist, was able to preserve the endothelial phenotype and ameliorate the progression of fibrosis in cells as well as in a murine model of heart disease [9], demonstrating that it was responsible for the total pool of cardiac fibroblasts. According to this evidence, Goumans' group confirmed the key role of the growth factor in EndMT in different in vitro and in vivo models [69].

More recently, Kong et al. [70] reported that accumulation and production of collagen and cardiac fibroblasts in human pathological patients were related to the process of EndMT.

Kovacic and colleagues also demonstrated that EndMT plays a main role in cardiac fibrosis that progresses to heart failure under hypertrophic cardiomyopathy, diabetesinduced cardiac fibrosis and genetic deficiency of PAI-1 in aged mice [2].

This is a relevant aspect, since a significant number of non-myocytes are present in the heart. In particular, it has been reported that about $64 \%$ of the non-myocyte cell population in the mouse and $54 \%$ in the human heart are endothelial cells [71].

\section{Biosynthesis, Metabolism and Sulfhydration of Cellular Targets by $\mathrm{H}_{2} \mathrm{~S}$}

Hydrogen sulfide $\left(\mathrm{H}_{2} \mathrm{~S}\right)$ is a gaseous mediator that is endogenously generated and exerts multiple effects. In particular, $\mathrm{H}_{2} \mathrm{~S}$ can be synthesized through enzymatic pathways, involving cystathionine $\beta$-synthase (CBS), cystathionine $\gamma$-lyase (CSE), cysteine aminotransferase (CAT) and 3-mercaptopyruvate sulfur transferase (3-MST) [72-77] (Figure 2).

All the enzymatic paths involve L-cysteine as the main substrate to be processed and are pirydoxal-5'-phosphate-dependent. Interestingly, biosynthesis of $\mathrm{H}_{2} \mathrm{~S}$ leads to other by-products, such as pyruvate or serine, respectively entering cell energetic metabolism or modulating vascular function through $\mathrm{NO}$ release [78,79]. All $\mathrm{H}_{2} \mathrm{~S}$-generating enzymes are widely distributed within the body with different relative expressions. In particular, CBS is the most abundant in the central nervous system, though it has been reported in different peripheral tissues, including vasculature, liver and kidney $[74,80,81]$. In addition, CSE is the major enzyme producing $\mathrm{H}_{2} \mathrm{~S}$ in the cardiovascular system and it has been found particularly in endothelial as well as smooth muscle cells, as well as in myocardiocytes $[73,82,83]$, where CAT and 3-MST have also been described [76,84]. 


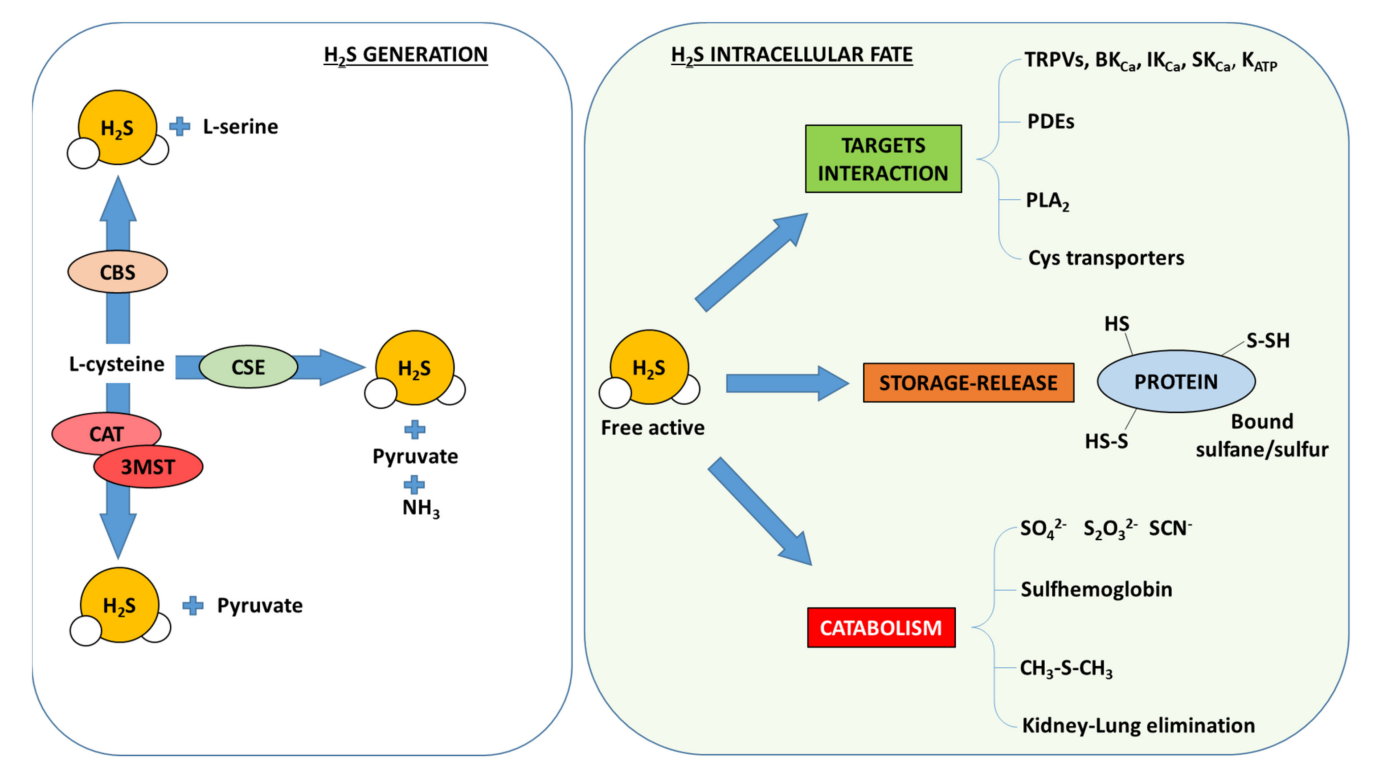

Figure 2. Biosynthesis and catabolism of $\mathrm{H}_{2} \mathrm{~S}$.

$\mathrm{H}_{2} \mathrm{~S}$ generated within the cells is free to interact with intracellular targets or diffuse outside the cell to modulate other cell functions. Several targets have been associated with $\mathrm{H}_{2} \mathrm{~S}$ action, including ion channels, such as ATP-sensitive potassium channels $\left(\mathrm{K}_{\mathrm{ATP}}\right)$, voltage-gated potassium channels (Kv7), transient receptor potential channel (TRPV) or L/T-type $\mathrm{Ca}^{2+}$ channels, enzymes such as phosphodiesterase, phospholipase A2, PI3K and Akt, or transcription factors such as STAT-3, nuclear factor erythroid 2-like 2 (Nrf-2) and NF-kB [82,85-89].

$\mathrm{H}_{2} \mathrm{~S}$ is mainly known to regulate vascular function by inducing vasodilation, through inhibition of phosphodiesterase and activation of $\mathrm{K}_{\mathrm{ATP}}$ and $\mathrm{Kv} 7$ channels; consistently, deletion of CSE leads to hypertension [90]. Nevertheless, $\mathrm{H}_{2} \mathrm{~S}$ regulates multiple functions within the body. In particular, it exerts anti-inflammatory properties by reducing proinflammatory mediators and activating resolution pathways [91-94].

Furthermore, $\mathrm{H}_{2} \mathrm{~S}$ has cytoprotective effects not only due to its scavenging properties, but also to other signaling pathways associated with an increase in glutathione (GSH) levels, reduction in $\mathrm{Ca}^{2+}$ influx and activation of mitochondrial ATP-sensitive potassium channels (mitoK ATP $_{\text {) }}$ [87,95-97].

The interaction mode between $\mathrm{H}_{2} \mathrm{~S}$ and its molecular targets depends on the target itself and, frequently, it occurs through a process known as protein sulfhydration $[98,99]$ (Figure 2). This mechanism consists of a chemical reaction on cysteine residues, generating a -S-SH moiety forming chemical species referred to as bound sulfane-sulfur. These species can modulate the protein activity and, at the same time, can store $\mathrm{H}_{2} \mathrm{~S}$ molecules that can be later released for biological actions. In the last decade, several examples of sulfhydration in the control of biological processes regulated by $\mathrm{H}_{2} \mathrm{~S}$ have been reported.

For instance, Altaany and co-workers showed that endothelial nitric oxide synthase (eNOS) activity is enhanced following sulfhydration through the enhancement of eNOS phosphorylation [100]. Another example of sulfhydration reaction has been reported for caspase 3, whose activity is suppressed, preventing neuronal injury associated with ischemia/reperfusion (I/R) events [101]. Conversely, activity of NF-kB subunit p65 is enhanced following sulfhydration, resulting in suppression of the apoptotic pathway in macrophages following TNF $\alpha$ stimulus [102]. In addition, $\mathrm{H}_{2} \mathrm{~S}$ can also drive sulfhydration of peroxisome proliferator-activated receptor- $\gamma(\operatorname{PPAR} \gamma)$ at Cys 139, increasing its nuclear translocation to DNA, thus promoting expression of genes associated with adipogenesis [103]. This mechanism could explain the switch from glucose to triglycerides storage induced by $\mathrm{H}_{2} \mathrm{~S}$. 
Finally, $\mathrm{H}_{2} \mathrm{~S}$ has been observed to modulate, via sulfhydration, Keap1-Nrf-2 and promote the gene transcription of antioxidant agents. Recent evidence shows that $\mathrm{H}_{2} \mathrm{~S}$ can also increase Akt (Ser473) phosphorylation levels to improve damage in disease states [104].

Once $\mathrm{H}_{2} \mathrm{~S}$ has exerted its effects, although it is relatively stable in blood and intracellular/interstitial fluids, it enters a catabolic pathway, where it serves as a scavenger of free radicals or hemoglobin. This feature is crucial, since $\mathrm{H}_{2} \mathrm{~S}$ represents a relevant antioxidant molecule also involved in maintaining GSH/glutathione disulfide (GSSG) balance. Furthermore, $\mathrm{H}_{2} \mathrm{~S}$ can be methylated or oxidized, thus generating multiple byproducts, including sulfate, sulfide or thiosulfate, all of which are excreted via the urinary tract [105]. $\mathrm{H}_{2} \mathrm{~S}$ can also be exhaled in breath, as demonstrated in animals and human volunteers following intravenous administration of NaHS [106,107]. However, despite the massive amounts of studies describing $\mathrm{H}_{2} \mathrm{~S}$ biosynthesis pathways, little is known about its metabolism/elimination, apart from the chemical/biochemical reactions described above (Figure 2).

\section{Contribution of Hydrogen Sulfide in Cardiovascular Fibrosis Associated with EndMT}

\subsection{Vascular Fibrosis and Hydrogen Sulfide}

$\mathrm{H}_{2} \mathrm{~S}$ is an important endogenous mediator with a key role in the cardiovascular system. Several studies have demonstrated a possible connection with TGF- $\beta$, and therefore its benefits on vascular fibrosis. In this regard, it is noteworthy to underline that Mallat and co-workers have confirmed that inhibition of TGF- $\beta$ signaling could promote the development of atherosclerosis with decreased collagen content in $\mathrm{ApoE}^{-/-}$mice [108]. This also occurs in uremia-accelerated atherosclerosis (UAAS), a common condition in patients with diabetic nephropathy. Indeed, the $\mathrm{CSE} / \mathrm{H}_{2} \mathrm{~S}$ system displays a protective role in UAAS. $\mathrm{Lu}$ and colleagues have demonstrated in a recent study that the use of $\mathrm{NaHS}$, a hydrophilic fast $\mathrm{H}_{2} \mathrm{~S}$ release, could suppress the formation of atherosclerosis via the degradation of TGF- $\beta$, as well as the reduction of smad3 phosphorylation. Therefore, the $\mathrm{H}_{2} \mathrm{~S}$ pathway regulates TGF- $\beta$ / smad3 signaling in UAAS mice, suggesting that the TGF- $\beta$ / smad 3 axis is responsible for $\mathrm{CSE} / \mathrm{H}_{2} \mathrm{~S}$-dependent vascular protection. Moreover, such effect is specific for $\mathrm{H}_{2} \mathrm{~S}$, since CSE inhibitors, such as propargylglycine, can conversely accelerate the atherosclerosis development [109]. This evidence highlights that the control operated by $\mathrm{H}_{2} \mathrm{~S}$ over TGF- $\beta$ signaling, crucial for EndMT, could slow down the whole fibrotic process.

Interestingly, CSE-knockout mice fed an atherogenic diet exhibited severe atherosclerosis, suggesting that the $\mathrm{CSE} / \mathrm{H}_{2} \mathrm{~S}$ pathway is somehow crucial to limit atherosclerosis development $[110,111]$, which is also dependent on activation of inflammatory macrophages [112].

However, the mechanisms underlying the effects of $\mathrm{H}_{2} \mathrm{~S}$ in the suppression of fibrosis are different and involve diverse pathways, and thus have to be found in its pleiotropic actions [113]. For instance, vascular fibrosis can develop following chronic hypertension and vasorelaxant effects driven by the $\mathrm{H}_{2} \mathrm{~S}$ pathway control fibrotic process by reducing blood pressure, through the modulation of channels' activity, cyclic guanosine monophosphateprotein kinase G (cGMP-PKG) pathways [114,115] and inhibition of angiotensin-converting enzyme (ACE) [116]. Although vasorelaxation can induce beneficial action over fibrosis per se, the inhibitory activity of $\mathrm{H}_{2} \mathrm{~S}$ on ACE also abrogates vascular fibrosis associated with AngII proliferative pathways. Another alternative mechanism involving $\mathrm{H}_{2} \mathrm{~S}$ signaling in the control of vascular fibrosis is associated with its anti-inflammatory properties, since $\mathrm{H}_{2} \mathrm{~S}$ shows beneficial effects in cardiovascular remodeling through suppression of CD11b-positive leukocytes' migration [117]. Furthermore, the reduction of oxidative stress in endothelial cells operated by $\mathrm{H}_{2} \mathrm{~S}$ can also contribute to its antifibrotic properties [118]. It is well-known that the activation of the eNOS/NO pathway is a crucial event in the control of vascular homeostasis, and recent findings report that $\mathrm{H}_{2} \mathrm{~S}$ shows an interplay with eNOS activation [78]. Indeed, $\mathrm{H}_{2} \mathrm{~S}$ shows protective effects in hypertensive cardiovascular disease and this effect is mediated by the eNOS/NO axis $[79,119]$. 
In addition, the endogenous $\mathrm{CSE} / \mathrm{H}_{2} \mathrm{~S}$ system has been shown to protect against the formation of UAAS via an alternative pathway involving the activation of protein kinase CbII (CPKCbII) / Akt signaling [120]. Thus, it should not be surprising that $\mathrm{H}_{2} \mathrm{~S}$ biosynthesis as well as CSE expression drop down in conditions of vascular calcification [121] or following the development of neointimal hyperplasia associated with induction of balloon injury. Again, this effect is reversed by $\mathrm{H}_{2} \mathrm{~S}$ treatment [122].

A typical risk factor for vascular fibrosis is hyperhomocysteinemia (HHcy), together with hypertension, hyperglycemia and dyslipidemia [52]. HHcy is characterized by high tissue and plasma homocysteine (Hcy) levels and it is mainly due to impaired renal clearance and malnutrition [123]. HHcy leads to vascular fibrosis, causing several disease conditions, including peripheral and cerebrovascular coronary occlusion as well as venous thromboembolism [124-126]. The link between HHcy and vascular fibrosis is found upon an excessive ECM deposition, together with unbalanced elastin/collagen proportions occurring through an increase of intracellular calcium release [127]. The profibrotic effect caused by Hcy is due to activation of MMPs, involved in the atherosclerotic plaque formation, leading to the alteration of ECM metabolism and the promotion of collagen deposition [128]. The interplay between $\mathrm{Hcy}$ and $\mathrm{H}_{2} \mathrm{~S}$ has been shown by Sen and colleagues as they demonstrated that activation of both MMP-2 and MMP-9 by HHcy was controlled following $\mathrm{H}_{2} \mathrm{~S}$ supplementation [129]. Of course, this is not the only study reporting the link between $\mathrm{H}_{2} \mathrm{~S}$ and Hcy, as both are part of a complex network of biochemical reactions referred to as the trans-sulfhydration pathway. Indeed, several reports show that high levels of Hcy can inhibit CSE activity [130]. Thus, in a pathological condition, HHcy can alter the whole trans-sulfhydration pathway through this mechanism [131]. Therefore, such a condition results in a drop of endogenous levels of $\mathrm{H}_{2} \mathrm{~S}$ due to a suppressed biosynthesis within the body. The accumulating evidence indicating $\mathrm{H}_{2} \mathrm{~S}$ as a crucial controller of vascular function leads to the straightforward conclusion that a lack of it results in pathological conditions affecting vascular tissues, including hypertension and fibrosis. Thus, it is not surprising that SG1002, a donor of $\mathrm{H}_{2} \mathrm{~S}$, is able to normalize the histological and molecular scores for hypertrophy and fibrosis, leading to a decrease in collagen accumulation in HHcy mice and, consequently, preventing vascular fibrosis [123].

Interestingly, a key point is also represented by the association between the fibrotic process, hypertension and AngII. As mentioned earlier, hypertension is a condition resulting from vascular fibrosis and might also be linked to Hcy levels. Indeed, Hcy induced the activation of MMP-9 together with the synthesis of collagen in endothelial cells, and this mechanism is driven by $\mathrm{AT}_{1}$-receptor activation by AngII [132]. Therefore, when an HHcy condition occurs, a reduction in $\mathrm{H}_{2} \mathrm{~S}$ biosynthesis is observed, and this can undermine its ability to inhibit ACE, resulting in increased AngII-dependent profibrotic stimulation [133]. This aspect has also been investigated in pulmonary vasculature, where administration of NaHS is able to decrease the mean pulmonary arterial pressure and to inhibit smooth muscle cells' proliferation in the pulmonary artery wall [134]. In addition, administration of exogenous $\mathrm{H}_{2} \mathrm{~S}$ also decreases the expression of collagen I and III in the pulmonary arteries, again suggesting that $\mathrm{H}_{2} \mathrm{~S}$ plays an important role in the development of the fibrotic process and vascular structural remodeling, thus controlling homeostasis in pulmonary arterial pressure [134].

It is intuitive that the use of therapeutic tools aiming to rescue physiological $\mathrm{H}_{2} \mathrm{~S}$ levels could represent a possible way to tackle the fibrotic process as well as other vascularbased impairments such as hypertension at different levels (Figure 3). Indeed, $\mathrm{H}_{2} \mathrm{~S}$ could modulate activation of the EndMT process as well as interfere with intermediate steps towards fibrosis. 


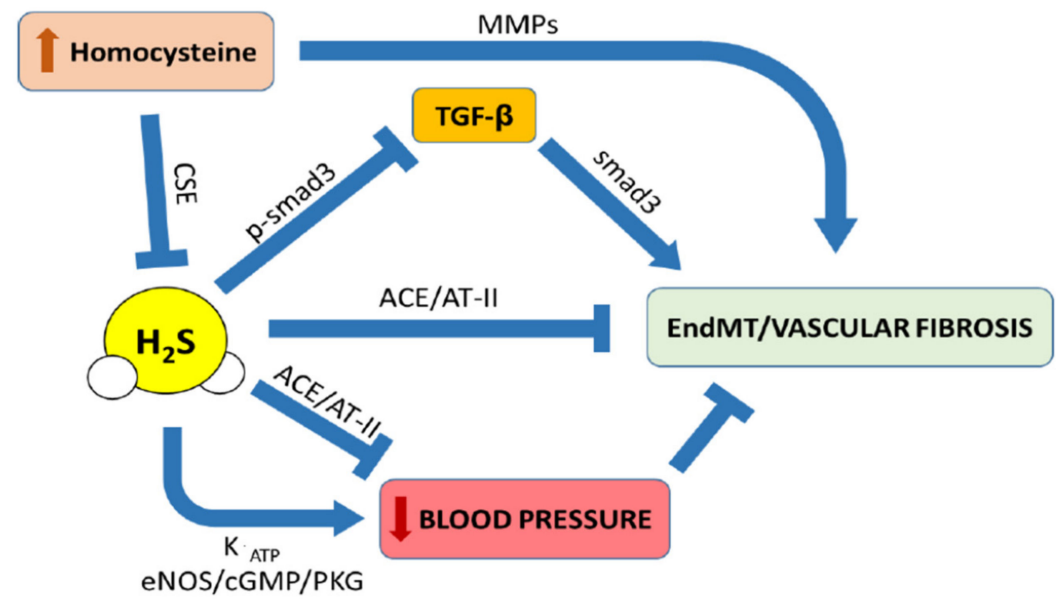

Figure 3. Multiple pathways associated with the effects of $\mathrm{H}_{2} \mathrm{~S}$ against vascular fibrosis.

\subsection{Cardiac Fibrosis and Hydrogen Sulfide}

Necrosis of cardiomyocytes in ischemic hearts triggers a strong inflammatory response and promotes interstitial and perivascular fibrosis due to biochemical, geometric and biomechanical changes of the ventricular wall not affected by the lesion [135]. The high production of pro-inflammatory cytokines (TNF- $\alpha$, IL-1 $\beta$ and IL-6) accompanies myocardial damage and hypertrophic tissue remodeling, contributing to the deposition of fibrotic tissue.

Interestingly, a reduction of $\mathrm{H}_{2} \mathrm{~S}$ levels and of CSE expression has been found in postischemic hearts [136]. Furthermore, $\mathrm{H}_{2} \mathrm{~S}$ levels have been found to be inversely correlated with the severity of coronary heart disease [137].

Indeed, $\mathrm{H}_{2} \mathrm{~S}$ shows cardioprotective activity against I/ $\mathrm{R}$ injury and it is considered an important modulator of the ischemic preconditioning process. The mechanisms of action responsible for the effects of $\mathrm{H}_{2} \mathrm{~S}$ are heterogeneous, for instance, protein sulfhydration of mitoK $\mathrm{ATP}_{\mathrm{AT}}$ and mitochondrial voltage-gated potassium channels (mitoKv7). It is noteworthy that Kv7.4 channels have been recently described in cardiac mitochondria, where they seem to play a cardioprotective role, in inhibition of mast cell degranulation and inflammatory processes, as well as in antioxidant and pro-angiogenic action [96,138]. $\mathrm{H}_{2} \mathrm{~S}$ seems to also be involved in suppression of pro-fibrotic mechanisms associated with myocardial ischemia through the involvement of different signaling pathways, such as Nrf2 [139-141], signaling pathways involving miRNAs [136,142,143] and mitochondrial protection mechanisms [104,144-147].

Experimental evidence shows that $\mathrm{NaHS}$ and slow-release $\mathrm{H}_{2} \mathrm{~S}$ donors such as AP39, diallyl disulfide (DADS) and GYY4137 are able to reduce oxidative stress and apoptotic mechanisms [148-150], mitochondrial permeability transition pore (mPTP) opening [144-146], inflammatory responses and cardiomyocyte death [151] and iNOS expression in experimental models of myocardial infarction [152]. NaHS is also able to increase heme oxygenase-1 (HO-1) expression [152], to promote pathways of GSK-3 $\beta$ / $\beta$-catenin [153], cGMP-dependent PKG/phospholamban [154] and to promote angiogenesis [155] and autophagy in elderly hearts [156,157].

GYY4137 preserves cardiac function, attenuates adverse remodeling and can exert post-ischemic cardioprotective effects. Indeed, hearts treated with GYY4137 had left ventricular fibrosis significantly lower than untreated hearts after myocardial infarction. Greater blood vessel density was found in the left ventricular scar area of the GYY4137treated animals compared to all other infarcted groups. Despite preserved left ventricular structure and function, treatment with GYY4137 increased the levels of atrial natriuretic 
peptide (ANP) and brain natriuretic peptide (BNP) in association with increased cGMP levels, parallel to higher cGMP-type I protein kinase (cGKI) levels [158].

Daily intraperitoneal administration of GYY4137 for 4 weeks to spontaneously hypertensive rats (SHR) decreased systolic blood pressure and inhibited myocardial fibrosis. This kind of treatment reduced the collagen deposition in the left ventricle, the ratio of perivascular collagen area vs. lumen area in perivascular regions and the concentration of hydroxyproline, collagen I and III mRNA expression and cross-linked collagen. GYY4137 also inhibited AngII-induced neonatal rat cardiac fibroblast proliferation, reduced the number of S-phase fibroblasts, decreased the expression and protein synthesis of collagen I and III mRNA, attenuated oxidative stress and suppressed $\alpha$-SMA, by modulating the expression of TGF- $\beta 1$ and the phosphorylation of smad2. These results showed that GYY4137 improved myocardial fibrosis, possibly through a mechanism involving inhibition of oxidative stress, blockade of the TGF- $\beta 1 /$ smad 2 signaling pathway and decreased expression of $\alpha$-SMA in cardiac fibroblasts [150].

Even more innovative $\mathrm{H}_{2} \mathrm{~S}$ donors, such as ADT-OH $\left(\mathrm{H}_{2} \mathrm{~S}\right.$-aspirin hybrid molecule) or ZYZ-802 (a cysteine derivative), were able to positively intervene in the ischemic lesion by activating the AMPK signaling pathway [146] and reducing the miRNA-30 family [136].

Polhemus and co-workers demonstrated that administration of diallyl trisulfide (DATS), a long-acting $\mathrm{H}_{2} \mathrm{~S}$-donor organic polysulfide compound present in garlic, could attenuate left ventricular dilatation and dysfunction in a model of pressure-overload heart failure, attenuating the development of perivascular and intermuscular fibrosis and then cardiac hypertrophy [159].

Finally, it is interesting that SG-1002, an orally active $\mathrm{H}_{2} \mathrm{~S}$ donor, is able to positively act in the fibrotic damage following a heart failure condition and in general of myocardial dysfunction, favoring the adiponectin-AMPK signaling pathway [160] and increasing the bioavailability of NO [161].

The metabolic dysregulation characteristic of diabetes, including hyperglycemia, hyperlipidemia and oxidative stress, causes the death of cardiomyocytic cells. The early stages of cardiac remodeling following diabetes are generally asymptomatic, with myocardial changes and damage almost exclusively at the molecular level. In the middle phase of remodeling, progressive hypertrophy of cardiomyocytes and myocardial fibrosis result in a reduced ejection fraction [162].

In patients with diabetes, as well as in rats treated with STZ, downregulation of the gene expression of the enzymes involved in the endogenous biosynthesis of $\mathrm{H}_{2} \mathrm{~S}$, with consequent reduction of circulating levels of $\mathrm{H}_{2} \mathrm{~S}$, was frequently found [163-165]. Growing evidence suggests that $\mathrm{H}_{2} \mathrm{~S}$ exogenous administration could exert cardioprotective effects in these pathological conditions. There is evidence that the JAK/STAT signaling pathway participates in the protective effects of exogenous $\mathrm{H}_{2} \mathrm{~S}$ against myocardial fibrosis in diabetes mellitus, though other studies point to an involvement of the $\mathrm{H}_{2} \mathrm{~S}$-forkhead box protein $\mathrm{O} 1$ (FoxO1) pathway in the pathogenesis of diabetic cardiomyopathy. In this regard, in a rat diabetic model induced by STZ administration, a condition of myocardial fibrosis was related to a significant decrease in the expression of tissue inhibitor of metalloproteinase-1 (TIMP1) and MMP2 and an increase in the expression of MMP7, MMP11, MMP13 and MMP16. These changes were significantly reversed after treatment with NaHS, improving myocardial hypertrophy and collagen deposition. This also happened through the engagement of other types of cellular mediators, including the reduction of the expression of Grp78, caspase-12 and CHOP [166]. This evidence suggests that $\mathrm{H}_{2} \mathrm{~S}$ could attenuate diabetes-induced cardiac fibrosis through the modulation of MMP/TIMP expression, the regulation of TGF- $\beta 1$ and other possible intracellular pathways, including the regulation of the PKC-ERK1/2/MAPK signaling pathway and the inhibition of inflammatory reactions [167-169].

Subsequent studies confirmed the protective effect of $\mathrm{H}_{2} \mathrm{~S}$ against diabetes-induced myocardial fibrosis and demonstrated that it was also associated with the attenuation of autophagy through upregulation of the PI3K/Akt1 signaling pathway [166]. 
In 2018, Liu et al. found that the myocardial cell matrix was markedly disordered in diabetic rats; in fact, both myocardial interstitial fibrosis and collagen III deposition were increased. The expression of TGF- $\beta$, eIF $2 \alpha$, GRP94, caspase- 3, TNF- $\alpha$, NF- $\kappa$ B, MDA and 4-HNE were significantly increased, the expression of JAK-1/2 and STAT1/3/5/6 were upregulated, while CSE, SOD, GSH and $\mathrm{Bcl}-2$ were downregulated. Compared to the diabetic group, these changes were reversed in the $\mathrm{H}_{2} \mathrm{~S}$ group [164].

Likewise, GYY4137 improved HG-induced oxidative stress and apoptosis in hearts. In particular, $\mathrm{H}_{2} \mathrm{~S}$ induced FoxO1 phosphorylation and nuclear exclusion with an Aktindependent mechanism, supporting the idea that $\mathrm{H}_{2} \mathrm{~S}$ can also inhibit dilated cardiomyopathy progression through this transcription factor [170].

Finally, circulating and cardiac $\mathrm{H}_{2} \mathrm{~S}$ levels were analyzed in a mouse model of high-fat diet-induced cardiomyopathy (HFD). HFD feeding for 24 weeks contributed to reduce both circulating and cardiac $\mathrm{H}_{2} \mathrm{~S}$ and induced hallmarks of type 2 diabetes. Marked cardiac dysfunction, cardiac hypertrophy and fibrosis were also observed. SG-1002 restored physiological levels of the gasotransmitter, improved some of the metabolic disorder markers and reduced diet-induced cardiac dysfunction. Further analysis revealed that $\mathrm{H}_{2} \mathrm{~S}$ therapy restored adiponectin levels and suppressed cardiac stress typical of HFD feeding [160].

Mice deficient in the $\mathrm{H}_{2} \mathrm{~S}$-producing enzyme, cystathionine $\gamma$-lyase (CSE KO), showed reduced cardiac mitochondrial content compared to wild-type hearts. In contrast, mice overexpressing CSE (CSE Tg) and mice supplemented with SG-1002 showed improved cardiac mitochondrial content. Further analysis revealed that cardiac $\mathrm{H}_{2} \mathrm{~S}$ levels affected nuclear localization and transcriptional activity of proliferator-activated peroxisome receptor $\gamma$ coactivator $1 \alpha(\mathrm{PGC} 1 \alpha)$. Studies aimed at evaluating the underlying mechanisms found that $\mathrm{H}_{2} \mathrm{~S}$ required AMPK to induce PGC1 $\alpha$ signaling and mitochondrial biogenesis. Restoring $\mathrm{H}_{2} \mathrm{~S}$ levels with SG-1002 in the context of heart failure increased cardiac mitochondrial content and improved mitochondrial respiration, the efficiency of ATP production and heart function [171].

In 2017, Liang et al. investigated the role of $\mathrm{H}_{2} \mathrm{~S}$ in myocardial fibrosis induced by chronic alcohol intake. A mouse model of cardiomyopathy was induced by administration of $4 \%$ ethanol solution in drinking water for 12 weeks. In this experimental condition, NaHS showed positive effects on myocardial fibrosis and deposition of collagen [172].

In 2018, Liu et al. investigated the role and regulatory mechanism of $\mathrm{H}_{2} \mathrm{~S}$ in the improvement of thyroxine-induced rat myocardial fibrosis through autophagy interference by regulation of the PI3K/AKT1 signaling pathway activity and the expression of related miRNA. In the thyroxine group, myocardial fibrosis was more significant, protein expression of PI3K/AKT and autophagy-related proteins were significantly decreased, as well as miR-221 expression if compared to the control group, while miR-21, miR-34a and miR-214 expressions were significantly higher. Conversely, all of the changes mentioned above were reversed with $\mathrm{H}_{2} \mathrm{~S}$ treatment, which demonstrated the positive function of this gasotransmitter in ameliorating thyroxine-induced myocardial fibrosis in rats. The mechanism of this enhancement may be correlated with autophagy triggered by the upregulation of the expression of the PI3K/AKT signaling pathway and by the downregulation of miR-21, miR-34a and miR214 expressions [173] (Figure 4). 


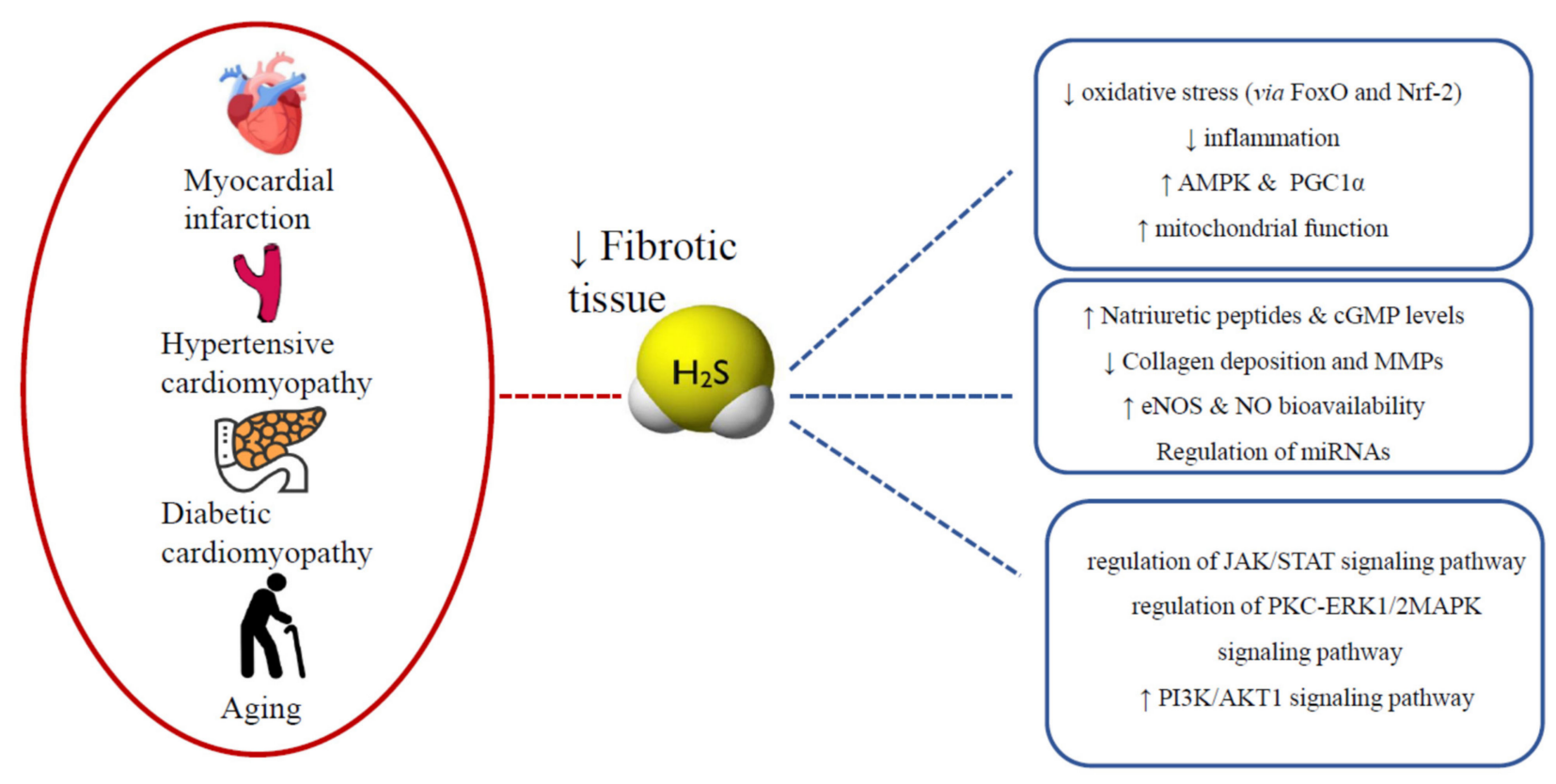

Figure 4. Multitarget effects of $\mathrm{H}_{2} \mathrm{~S}$ against myocardial fibrosis.

\section{Role of Hydrogen Sulfide in EndMT}

A growing body of evidence shows that $\mathrm{H}_{2} \mathrm{~S}$ plays a relevant role in the modulation of EMT, in several types of fibrosis. In this regard, Fang and colleagues demonstrated that a deficient endogenous CSE $/ \mathrm{H}_{2} \mathrm{~S}$ system was at the basis of the development of bleomycininduced pulmonary fibrosis in rats. Exogenous application of NaHS interfered with lung fibrosis pathogenesis, through reduction of oxidative stress and suppression of migration, proliferation and myofibroblast trans-differentiation in human lung fibroblast cells. This evidence suggested that $\mathrm{H}_{2} \mathrm{~S}$ could be an important regulator of pathogenesis of pulmonary fibrosis [174]. Later, they observed that $\mathrm{H}_{2} \mathrm{~S}$ attenuated fibrosis induced by treatment with TGF- $\beta 1$ in alveolar epithelial cells and by reduction of smad2/3 phosphorylation, but independently from activation of $\mathrm{K}_{\mathrm{ATP}}$, a well-known target of the gasotransmitter involved in cell protection [175].

A more recent study indicates that exogenous $\mathrm{H}_{2} \mathrm{~S}$ inhibited paraquat-induced EMT in human alveolar epithelial cells through regulating the TGF- $\beta 1 / \operatorname{smad} 2 / 3$ signaling pathway, also providing a novel idea for the clinical treatment of poisoning [176].

Indeed, the anti-fibrotic effects of $\mathrm{H}_{2} \mathrm{~S}$ have been widely investigated in airways, to evaluate its contribution in the maintenance of respiratory function following the exposition to environmental toxins. In this context, GYY-4137 inhibited TGF- $\beta 1$-induced cell morphological changes and EMT in human bronchial epithelial cells [177]. Nickel compounds are known to be common environmental and occupational carcinogens. In cell models, nickel is able to upregulate the protein levels of TGF- $\beta 1$ and of smad $2 / 3$ phosphorylation, triggering the EMT process. Conversely, exogenous NaHS alleviates the nickel-induced EMT and the migration ability of lung cancer cells, indicating that NaHS might also have protective effects against nickel-induced lung cancer progression [60].

EMT has also been described as a key regulator of cancer progression and metastasis, and in this regard, Wang and colleagues demonstrated that $\mathrm{H}_{2} \mathrm{~S}$ could modulate angiogenesis and the progression of non-small cell lung cancer via HIF- $1 \alpha$ activation and stimulation of VEGF expression [60]. EMT has also been described during peritoneal fibrosis, to explain the loss of mesothelial cells and the occurrence of myofibroblasts. It is a characteristic condition described as a major cause of ultrafiltration failure of peritoneal dialysis. In fact, under HG stimulus, mesothelial cells undergo EMT, leading to a loss of epithelial tight junctions and an increase of the myofibroblast marker, $\alpha$-SMA. In that experimental model, 
rats treated with glucose plus lipopolysaccharide for 28 days produced peritoneal fibrosis, and of note, NaHS reduced the deposition of collagen in the sub-mesothelial zone and inhibited inflammatory markers and the TGF- $\beta 1 /$ smad signaling pathway [178].

In agreement with the previous evidence, $\mathrm{H}_{2} \mathrm{~S}$ counteracted Ang II-induced EMT in renal tubular epithelial cells, through mechanisms involving direct and indirect inactivation of TGF- $\beta 1$. This is the first work, to our knowledge, in which a possible mechanistic insight into the anti-fibrotic actions of $\mathrm{H}_{2} \mathrm{~S}$ has been suggested. The authors supposed that beyond indirect antioxidant action, $\mathrm{H}_{2} \mathrm{~S}$ could affect AngII-induced EMT through direct effects on the structural modifications at the level of an inactivated form of TGF- $\beta 1$. Indeed, the cleavage of the disulfide bond in the active dimeric TGF- $\beta 1$ by $\mathrm{H}_{2} \mathrm{~S}$ could represent a key modification of Cys residues [60].

Despite the body of evidence collected on the putative role of $\mathrm{H}_{2} \mathrm{~S}$ in the modulation of EMT, only recently has the first study been published, revealing that $\mathrm{H}_{2} \mathrm{~S}$ can attenuate EndMT induced by ER stress at the cardiovascular level. In particular, Ying and colleagues hypothesized that $\mathrm{H}_{2} \mathrm{~S}$ is able to suppress the EndMT in human umbilical endothelial cells submitted to endoplasmic reticulum stress. Under stimuli, EndMT is triggered, upregulating the phosphorylation of smad2, independent of the TGF- $\beta$ pathway. The Src pathway is also involved in EndMT and is activated during ER stress. It is noteworthy that the treatment with $\mathrm{H}_{2} \mathrm{~S}$ reverted EndMT, and conversely, the inhibition of Src kinase, by specific antagonists or silencing, abolished the protective effects of $\mathrm{H}_{2} \mathrm{~S}$ [179].

More recently, a preventive role of $\mathrm{H}_{2} \mathrm{~S}$ in the vascular remodeling of pulmonary arterial hypertension has been hypothesized. Indeed, EndMT has been suggested as a process involved in fibrosis in patients with pulmonary artery hypertension and in several animal models. In human pulmonary artery endothelial cells, transfection with CSE plasmid or exogenous $\mathrm{H}_{2} \mathrm{~S}$ significantly repressed TGF- $\beta 1$-induced expression of the mesenchymal markers and upregulated the expression of the endothelial markers, accompanied by the suppression of the NF- $\mathrm{kB} /$ Snail pathway. On the contrary, pretreatment with an inhibitor of CSE reversed it, revealing another possible mechanism through which $\mathrm{H}_{2} \mathrm{~S}$ may play a preventive role towards pulmonary hypertension. Furthermore, the authors speculated that $\mathrm{H}_{2} \mathrm{~S}$ could regulate the epithelial/endothelial phenotypic transition by sulfhydrating NF-kB, or via Snail at the level of cysteine residues [180].

Although not directly related to the EndMT, several studies show anti-fibrotic effects of $\mathrm{H}_{2} \mathrm{~S}$ and its ability to regulate underlying pathways. For example, GYY4137 improved myocardial fibrosis by a mechanism involving the inhibition of the TGF- $\beta 1 /$ smad 2 signaling pathway and a decrease in $\alpha$-SMA expression in cardiac fibroblasts [150]. This pathway is implicated in the reduction of myocardial fibrosis promoted by a liposomal formulation of S-propargyl-cysteine and endowed with cardio-protection in in vitro and in vivo models of $I / R$ and in heart failure, and with angiogenetic effects. Importantly, in an in vivo model of heart failure, liposomal ZYZ-802 markedly inhibited myocardial fibrosis via the inhibition of the TGF- $\beta 1 /$ smad signaling pathway [181]. However, in rat diabetic myocardial fibrosis, $\mathrm{H}_{2} \mathrm{~S}$ had preventive effects through negative regulation of the Wnt-pathway and downregulation of TGF- $\beta$ / smad3 signaling [169]. It is well-known that the $\mathrm{CSE}_{-} \mathrm{H}_{2} \mathrm{~S}$ pathway shows antiatherogenic effects and it may reduce the size of atherosclerotic lesions at the vascular level. On the other hand, the role of EndMT in the progression of atherosclerosis is also recognized. It is noteworthy that a common molecular mechanism has been identified for $\mathrm{H}_{2} \mathrm{~S}$ and EndMT, showing that in $\mathrm{Apo}^{-/-}$mice treated with NaHS, TGF- $\beta$ protein expression and smad 3 phosphorylation decreased. Conversely, the inhibition of the $\mathrm{CSE}-\mathrm{H}_{2} \mathrm{~S}$ pathway reverted it. Therefore, at least in part, the protective effects of $\mathrm{H}_{2} \mathrm{~S}$ at the vascular level are related to inhibition of endothelial phenotype maintenance [109].

\section{Conclusions}

In the cardiovascular system, fibrosis proceeds through multiple steps by way of tissue reparation after damage, ultimately resulting in excessive deposition of connective tissue that alters the morphology and functionality of vessels and the heart. The pivotal role of 
the EndMT process is emerging in these pathological changes, and therefore therapeutic interventions focused to containment or inversion of the transition from endothelial to mesenchymal phenotype are an interesting area of intense research today. In this context, $\mathrm{H}_{2} \mathrm{~S}$ and molecules able to release $\mathrm{H}_{2} \mathrm{~S}$ have recently been associated with anti-fibrotic properties in the cardiovascular system. Despite the limited evidence in animal and human studies, several pathways recognized as part of EndMT (TGF- $\beta$ ) seem to be involved in the protective effects of this gasotransmitter, thus suggesting that $\mathrm{H}_{2} \mathrm{~S}$ could be a relevant physiological modulator of the fibrotic process. Of course, this review could open a discussion about the need for further studies confirming published evidence and aiming to better define the role of $\mathrm{H}_{2} \mathrm{~S}$ in the EndMT / fibrosis process. Indeed, taking into account the different diseases associated with a negative regulation of $\mathrm{H}_{2} \mathrm{~S}$ levels, molecules able to release $\mathrm{H}_{2} \mathrm{~S}$ could represent a useful tool to slow down the progression of cardiovascular fibrosis as well as a possible approach to pursue in pharmacological therapy.

Author Contributions: Conceptualization, L.T.; Writing-Original Draft Preparation, L.T., V.B., R.M. and L.F.; Writing-Review and Editing, L.T. and V.C.; Supervision, V.C.; Funding Acquisition, V.C. All authors have read and agreed to the published version of the manuscript.

Funding: This work has been supported by PRIN 2017, entitled "Hydrogen Sulfide in the Vascular Inflamm-Aging: role, therapeutic opportunities and development of novel pharmacological tools for age-related cardiovascular diseases (SVAgO)".

Conflicts of Interest: The authors declare no conflict of interest.

\section{Abbreviations}

\begin{tabular}{|c|c|}
\hline ALK & activin receptor-like kinase \\
\hline$\alpha-\mathrm{SMA}$ & $\alpha$-smooth muscle actin \\
\hline AMPK & AMP-activated protein kinase \\
\hline AngII & angiotensin II \\
\hline $\mathrm{ACE}$ & angiotensin-converting enzyme \\
\hline $\mathrm{K}_{\text {ATP }}$ & ATP-sensitive potassium channels \\
\hline ANP & atrial natriuretic peptide \\
\hline AVC & atrioventricular canal \\
\hline BMP & bone morphogenetic protein \\
\hline BMPRs & bone morphogenetic protein receptors \\
\hline BNP & brain natriuretic peptide \\
\hline cGKI & cGMP-type I protein kinase \\
\hline cGMP-PKG & cyclic guanosine monophosphate-protein kinase $G$ \\
\hline CBS & cystathionine $\beta$-synthase \\
\hline CSE & cystathionine $\gamma$-lyase \\
\hline CAT & cysteine aminotransferase \\
\hline DCM & diabetic cardiomyopathy \\
\hline DATS & diallyl trisulfide \\
\hline EndM & endothelial mesenchymal transition \\
\hline eNOS & endothelial nitric oxide synthase \\
\hline EMT & epithelial mesenchymal transition \\
\hline ET1 & endothelin 1 \\
\hline ECM & extracellular matrix \\
\hline ERK & extracellular-signal-regulated kinase \\
\hline FGF & fibroblast growth factor \\
\hline FoxO1 & forkhead box protein $\mathrm{O} 1$ \\
\hline GSH & glutathione \\
\hline GSSG & glutathione disulfide \\
\hline HDL & high-density lipoproteins \\
\hline $\mathrm{HG}$ & high glucose \\
\hline HcyHFD & homocysteinehigh-fat diet \\
\hline $\mathrm{H}_{2} \mathrm{~S}$ & hydrogen sulfide \\
\hline
\end{tabular}




\begin{tabular}{|c|c|}
\hline HHcy & hyperhomocysteinemia \\
\hline IL-1 $\beta$ & interleukin-1 $\beta$ \\
\hline IL-6 & interleukin-6 \\
\hline IFN- $\gamma$ & interferon gamma \\
\hline JAK & Janus kinase \\
\hline MEndT & mesenchymal-endothelial transition \\
\hline 3-MST & 3-mercaptopyruvate sulfur transferase \\
\hline mitoK $_{\mathrm{ATP}}$ & mitochondrial ATP-sensitive potassium channels \\
\hline mPTP & mitochondrial permeability transition pore \\
\hline MAPK & mitogen-activated protein kinase \\
\hline $\mathrm{NO}$ & nitric oxide \\
\hline Nrf-2 & nuclear factor erythroid 2-like 2 \\
\hline NF-kB & nuclear factor- $\mathrm{kB}$ \\
\hline oxLDL & oxidized low-density lipoproteins \\
\hline PI3K & phosphoinositide 3-kinase \\
\hline PGC1 $\alpha$ & proliferator-activated peroxisome receptor $\gamma$ coactivator $1 \alpha$ \\
\hline RASAL1 & RAS protein activator-like 1 \\
\hline STAT & signal transducer and activator of transcription \\
\hline SHR & spontaneously hypertensive rats \\
\hline MMP & metalloproteinase \\
\hline TGF- $\beta$ & transforming growth factor \\
\hline TRPV & transient receptor potential channel \\
\hline TNF- $\alpha$ & tumor necrosis factor- $\alpha$ \\
\hline VE-cadherin & vascular endothelial cadherin \\
\hline VEGF & vascular endothelial growth factor \\
\hline Kv7 & voltage-gated potassium channels \\
\hline UAAS & uremia-accelerated atherosclerosis \\
\hline
\end{tabular}

\section{References}

1. Trelstad, R.L.; Hay, E.D.; Revel, J.-P. Cell contact during early morphogenesis in the chick embryo. Dev. Biol. 1967, 16, 78-106. [CrossRef]

2. Kovacic, J.C.; Mercader, N.; Torres, M.; Boehm, M.; Fuster, V. Epithelial-to-mesenchymal and endothelial-to-mesenchymal transition: From cardiovascular development to disease. Circulation 2012, 125, 1795-1808. [CrossRef]

3. Sewduth, R.; Santoro, M.M. “Decoding” angiogenesis: New facets controlling endothelial cell behavior. Front. Physiol. 2016, 7, 306. [CrossRef]

4. Piera-Velazquez, S.; Li, Z.; Jimenez, S.A. Role of endothelial-mesenchymal transition (EndoMT) in the pathogenesis of fibrotic disorders. Am. J. Pathol. 2011, 179, 1074-1080. [CrossRef] [PubMed]

5. Ubil, E.; Duan, J.; Pillai, I.C.; Rosa-Garrido, M.; Wu, Y.; Bargiacchi, F.; Lu, Y.; Stanbouly, S.; Huang, J.; Rojas, M. Mesenchymalendothelial transition contributes to cardiac neovascularization. Nature 2014, 514, 585-590. [CrossRef]

6. Van Berlo, J.H.; Kanisicak, O.; Maillet, M.; Vagnozzi, R.J.; Karch, J.; Lin, S.-C.J.; Middleton, R.C.; Marbán, E.; Molkentin, J.D. C-kit + cells minimally contribute cardiomyocytes to the heart. Nature 2014, 509, 337-341. [CrossRef] [PubMed]

7. Ikenouchi, J.; Matsuda, M.; Furuse, M.; Tsukita, S. Regulation of tight junctions during the epithelium-mesenchyme transition: Direct repression of the gene expression of claudins/occludin by Snail. J. Cell Sci. 2003, 116, 1959-1967. [CrossRef] [PubMed]

8. Valcourt, U.; Kowanetz, M.; Niimi, H.; Heldin, C.-H.; Moustakas, A. TGF- $\beta$ and the Smad signaling pathway support transcriptomic reprogramming during epithelial-mesenchymal cell transition. Mol. Biol. Cell 2005, 16, 1987-2002. [CrossRef] [PubMed]

9. Zeisberg, E.M.; Tarnavski, O.; Zeisberg, M.; Dorfman, A.L.; McMullen, J.R.; Gustafsson, E.; Chandraker, A.; Yuan, X.; Pu, W.T.; Roberts, A.B. Endothelial-to-mesenchymal transition contributes to cardiac fibrosis. Nat. Med. 2007, 13, 952-961. [CrossRef]

10. Zeisberg, M.; Hanai, J.-i.; Sugimoto, H.; Mammoto, T.; Charytan, D.; Strutz, F.; Kalluri, R. BMP-7 counteracts TGF- $\beta 1-i n d u c e d$ epithelial-to-mesenchymal transition and reverses chronic renal injury. Nat. Med. 2003, 9, 964-968. [CrossRef] [PubMed]

11. Bhowmick, N.A.; Ghiassi, M.; Bakin, A.; Aakre, M.; Lundquist, C.A.; Engel, M.E.; Arteaga, C.L.; Moses, H.L. Transforming growth factor- $\beta 1$ mediates epithelial to mesenchymal transdifferentiation through a RhoA-dependent mechanism. Mol. Biol. Cell 2001, 12, 27-36. [CrossRef]

12. Massagué, J.; Gomis, R.R. The logic of TGF $\beta$ signaling. FEBS Lett. 2006, 580, 2811-2820. [CrossRef]

13. Brooks, W.W.; Conrad, C.H. Myocardial fibrosis in transforming growth factor $\beta 1$ heterozygous mice. J. Mol. Cell. Cardiol. 2000, 32, 187-195. [CrossRef]

14. Mercado-Pimentel, M.E.; Hubbard, A.D.; Runyan, R.B. Endoglin and Alk5 regulate epithelial-mesenchymal transformation during cardiac valve formation. Dev. Biol. 2007, 304, 420-432. [CrossRef]

15. Boyer, A.S.; Ayerinskas, I.I.; Vincent, E.B.; McKinney, L.A.; Weeks, D.L.; Runyan, R.B. TGF $\beta 2$ and TGF $\beta 3$ have separate and sequential activities during epithelial-mesenchymal cell transformation in the embryonic heart. Dev. Biol. 1999, 208, 530-545. [CrossRef] 
16. Xu, X.; Friehs, I.; Zhong Hu, T.; Melnychenko, I.; Tampe, B.; Alnour, F.; Iascone, M.; Kalluri, R.; Zeisberg, M.; Del Nido, P.J. Endocardial fibroelastosis is caused by aberrant endothelial to mesenchymal transition. Circ. Res. 2015, 116, 857-866. [CrossRef]

17. Koitabashi, N.; Danner, T.; Zaiman, A.L.; Pinto, Y.M.; Rowell, J.; Mankowski, J.; Zhang, D.; Nakamura, T.; Takimoto, E.; Kass, D.A. Pivotal role of cardiomyocyte TGF- $\beta$ signaling in the murine pathological response to sustained pressure overload. J. Clin. Investig. 2011, 121, 2301-2312. [CrossRef] [PubMed]

18. Zhang, Z.; Wang, J.-a.; Xu, Y.; Jiang, Z.; Wu, R.; Wang, L.; Chen, P.; Hu, X.; Yu, H. Menstrual blood derived mesenchymal cells ameliorate cardiac fibrosis via inhibition of endothelial to mesenchymal transition in myocardial infarction. Int. J. Cardiol. 2013, 168, 1711-1714. [CrossRef] [PubMed]

19. Kaartinen, V.; Voncken, J.; Shuler, C.; Warburton, D.; Heisterkamp, N.; Groffen, J. Abnormal lung development and cleft palate: Defects of epithelial-mesenchymal interaction in mice lacking TGF- $\beta 3$. Nat. Genet. 1995, 11, 415-421. [CrossRef] [PubMed]

20. Pardali, E.; Sanchez-Duffhues, G.; Gomez-Puerto, M.C.; Ten Dijke, P. TGF- $\beta$-induced endothelial-mesenchymal transition in fibrotic diseases. Int. J. Mol. Sci. 2017, 18, 2157. [CrossRef]

21. Robertson, I.B.; Horiguchi, M.; Zilberberg, L.; Dabovic, B.; Hadjiolova, K.; Rifkin, D.B. Latent TGF- $\beta$-binding proteins. Matrix Biol. 2015, 47, 44-53. [CrossRef]

22. Wermuth, P.J.; Li, Z.; Mendoza, F.A.; Jimenez, S.A. Stimulation of transforming growth factor- $\beta 1$-induced endothelial-tomesenchymal transition and tissue fibrosis by endothelin-1 (ET-1): A novel profibrotic effect of ET-1. PLoS ONE 2016, 11, e0161988. [CrossRef] [PubMed]

23. Hasan, M.; Neumann, B.; Haupeltshofer, S.; Stahlke, S.; Claudio Fantini, M.; Angstwurm, K.; Bogdahn, U.; Kleiter, I. Activation of TGF- $\beta$-induced non-Smad signaling pathways during Th17 differentiation. Immunol. Cell Biol. 2015, 93, 662-672. [CrossRef] [PubMed]

24. Cooley, B.C.; Nevado, J.; Mellad, J.; Yang, D.; Hilaire, C.S.; Negro, A.; Fang, F.; Chen, G.; San, H.; Walts, A.D. TGF- $\beta$ signaling mediates endothelial-to-mesenchymal transition (EndMT) during vein graft remodeling. Sci. Transl. Med. 2014, 6, ra227-ra234. [CrossRef] [PubMed]

25. Kovacic, J.C.; Dimmeler, S.; Harvey, R.P.; Finkel, T.; Aikawa, E.; Krenning, G.; Baker, A.H. Endothelial to mesenchymal transition in cardiovascular disease: JACC state-of-the-art review. J. Am. Coll. Cardiol. 2019, 73, 190-209. [CrossRef]

26. Zhang, H.; von Gise, A.; Liu, Q.; Hu, T.; Tian, X.; He, L.; Pu, W.; Huang, X.; He, L.; Cai, C.-L. Yap1 is required for endothelial to mesenchymal transition of the atrioventricular cushion. J. Biol. Chem. 2014, 289, 18681-18692. [CrossRef]

27. Wu, M.; Peng, Z.; Zu, C.; Ma, J.; Lu, S.; Zhong, J.; Zhang, S. Losartan attenuates myocardial endothelial-to-mesenchymal transition in spontaneous hypertensive rats via inhibiting TGF- $\beta$ /Smad Signaling. PLoS ONE 2016, 11, e0155730. [CrossRef]

28. Morikawa, M.; Derynck, R.; Miyazono, K. TGF- $\beta$ and the TGF- $\beta$ family: Context-dependent roles in cell and tissue physiology. Cold Spring Harb. Perspect. Biol. 2016, 8, a021873. [CrossRef] [PubMed]

29. Shu, Y.; Liu, Y.; Li, X.; Cao, L.; Yuan, X.; Li, W.; Cao, Q. Aspirin-triggered resolvin D1 inhibits TGF- $\beta 1$-induced EndMT through increasing the expression of smad7 and is closely related to oxidative stress. Biomol. Ther. 2016, 24, 132. [CrossRef]

30. Malhotra, R.; Burke, M.F.; Martyn, T.; Shakartzi, H.R.; Thayer, T.E.; O’Rourke, C.; Li, P.; Derwall, M.; Spagnolli, E.; Kolodziej, S.A. Inhibition of bone morphogenetic protein signal transduction prevents the medial vascular calcification associated with matrix Gla protein deficiency. PLoS ONE 2015, 10, e0117098. [CrossRef]

31. Timmerman, L.A.; Grego-Bessa, J.; Raya, A.; Bertrán, E.; Pérez-Pomares, J.M.; Díez, J.; Aranda, S.; Palomo, S.; McCormick, F.; Izpisúa-Belmonte, J.C. Notch promotes epithelial-mesenchymal transition during cardiac development and oncogenic transformation. Genes Dev. 2004, 18, 99-115. [CrossRef] [PubMed]

32. Zhou, X.; Chen, X.; Cai, J.; Chen, L.; Gong, Y.; Wang, L.; Gao, Z.; Zhang, H.; Huang, W.; Zhou, H. Relaxin inhibits cardiac fibrosis and endothelial-mesenchymal transition via the Notch pathway. Drug Des. Dev. Ther. 2015, 9, 4599. [CrossRef] [PubMed]

33. Aisagbonhi, O.; Rai, M.; Ryzhov, S.; Atria, N.; Feoktistov, I.; Hatzopoulos, A.K. Experimental myocardial infarction triggers canonical Wnt signaling and endothelial-to-mesenchymal transition. Dis. Models Mech. 2011, 4, 469-483. [CrossRef]

34. Działo, E.; Tkacz, K.; Błyszczuk, P. Crosstalk between TGF- $\beta$ and WNT signalling pathways during cardiac fibrogenesis. Acta Biochim. Pol. 2018, 65, 341-349. [CrossRef]

35. Xiang, F.-L.; Fang, M.; Yutzey, K.E. Loss of $\beta$-catenin in resident cardiac fibroblasts attenuates fibrosis induced by pressure overload in mice. Nat. Commun. 2017, 8, 1-12. [CrossRef] [PubMed]

36. Okayama, K.; Azuma, J.; Dosaka, N.; Iekushi, K.; Sanada, F.; Kusunoki, H.; Iwabayashi, M.; Rakugi, H.; Taniyama, Y.; Morishita, R. Hepatocyte growth factor reduces cardiac fibrosis by inhibiting endothelial-mesenchymal transition. Hypertension 2012, 59, 958-965. [CrossRef]

37. Widyantoro, B.; Emoto, N.; Nakayama, K.; Anggrahini, D.W.; Miyagawa, K.; Anggraeni, V.Y.; Suzuki, T.; Kisanuki, Y.Y.; Yanagisawa, M.; Hirata, K. 1 Endothelial Cell-derived Endothelin-1 Promotes Cardiac Fibrosis in Diabetic Heart through Stimulation of Endothelial to Mesenchymal Transition (Young Investigator's Award for International Students Finalists Lecture (YIA International), The 73rd Annual Scientific Meeting of The Japanese Circulation Society). Circ. J. Off. J. Jpn. Circ. Soc. 2009, 73, 73.

38. Cipriani, P.; Di Benedetto, P.; Ruscitti, P.; Capece, D.; Zazzeroni, F.; Liakouli, V.; Pantano, I.; Berardicurti, O.; Carubbi, F.; Pecetti, G. The endothelial-mesenchymal transition in systemic sclerosis is induced by endothelin- 1 and transforming growth factor- $\beta$ and may be blocked by macitentan, a dual endothelin-1 receptor antagonist. J. Rheumatol. 2015, 42, 1808-1816. [CrossRef]

39. Chrobak, I.; Lenna, S.; Stawski, L.; Trojanowska, M. Interferon- $\gamma$ promotes vascular remodeling in human microvascular endothelial cells by upregulating endothelin (ET)-1 and transforming growth factor (TGF) ß2. J. Cell. Physiol. 2013, 228, 1774-1783. [CrossRef] 
40. Lee, S.H.; Schloss, D.J.; Jarvis, L.; Krasnow, M.A.; Swain, J.L. Inhibition of angiogenesis by a mouse sprouty protein. J. Biol. Chem. 2001, 276, 4128-4133. [CrossRef]

41. Kim, D.H.; Kim, E.J.; Park, S.W. Dact2 is involved in the regulation of epithelial-mesenchymal transition. Biochem. Biophys. Res. Commun. 2020, 524, 190-197. [CrossRef]

42. Illigens, B.M.-W.; Berazaluce, A.C.; Poutias, D.; Gasser, R.; Pedro, J.; Friehs, I. Vascular endothelial growth factor prevents endothelial-to-mesenchymal transition in hypertrophy. Ann. Thorac. Surg. 2017, 104, 932-939. [CrossRef]

43. Jackson, A.O.; Zhang, J.; Jiang, Z.; Yin, K. Endothelial-to-mesenchymal transition: A novel therapeutic target for cardiovascular diseases. Trends Cardiovasc. Med. 2017, 27, 383-393. [CrossRef]

44. Dong, W.-q.; Chao, M.; Lu, Q.-h.; Chai, W.-1.; Zhang, W.; Chen, X.-y.; Liang, E.-s.; Wang, L.-b.; Tian, H.-1.; Chen, Y.-g. Prohibitin overexpression improves myocardial function in diabetic cardiomyopathy. Oncotarget 2016, 7, 66. [CrossRef]

45. Tang, R.; Li, Q.; Lv, L.; Dai, H.; Zheng, M.; Ma, K.; Liu, B. Angiotensin II mediates the high-glucose-induced endothelial-tomesenchymal transition in human aortic endothelial cells. Cardiovasc. Diabetol. 2010, 9, 1-7. [CrossRef] [PubMed]

46. Mishra, R.; Cool, B.L.; Laderoute, K.R.; Foretz, M.; Viollet, B.; Simonson, M.S. AMP-activated protein kinase inhibits transforming growth factor- $\beta$-induced Smad3-dependent transcription and myofibroblast transdifferentiation. J. Biol. Chem. 2008, 283, 10461-10469. [CrossRef] [PubMed]

47. Zhang, F.; Ren, X.; Zhao, M.; Zhou, B.; Han, Y. Angiotensin-(1-7) abrogates angiotensin II-induced proliferation, migration and inflammation in VSMCs through inactivation of ROS-mediated PI3K/Akt and MAPK/ERK signaling pathways. Sci. Rep. 2016, 6, 1-11. [CrossRef] [PubMed]

48. Hulshoff, M.S.; Xu, X.; Krenning, G.; Zeisberg, E.M. Epigenetic Regulation of Endothelial-to-Mesenchymal Transition in Chronic Heart Disease: Histone Modifications, DNA Methylation, and Noncoding RNAs. Arterioscler. Thromb. Vasc. Biol. 2018, 38, 1986-1996. [CrossRef] [PubMed]

49. Wynn, T.A. Cellular and molecular mechanisms of fibrosis. J. Pathol. A J. Pathol. Soc. Great Br. Irel. 2008, 214, 199-210. [CrossRef]

50. Jellis, C.; Martin, J.; Narula, J.; Marwick, T.H. Assessment of nonischemic myocardial fibrosis. J. Am. Coll. Cardiol. 2010, 56, 89-97. [CrossRef]

51. Disertori, M.; Masè, M.; Ravelli, F. Myocardial fibrosis predicts ventricular tachyarrhythmias. Trends Cardiovasc. Med. 2017, 27, 363-372. [CrossRef] [PubMed]

52. Lan, T.-H.; Huang, X.-Q.; Tan, H.-M. Vascular fibrosis in atherosclerosis. Cardiovasc. Pathol. 2013, 22, 401-407. [CrossRef]

53. Testai, L.; Citi, V.; Martelli, A.; Brogi, S.; Calderone, V. Role of hydrogen sulfide in cardiovascular ageing. Pharmacol. Res. 2020, 160, 105125. [CrossRef] [PubMed]

54. Souilhol, C.; Harmsen, M.C.; Evans, P.C.; Krenning, G. Endothelial-mesenchymal transition in atherosclerosis. Cardiovasc. Res. 2018, 114, 565-577. [CrossRef]

55. Krenning, G.; Barauna, V.G.; Krieger, J.E.; Harmsen, M.C.; Moonen, J.-R.A. Endothelial plasticity: Shifting phenotypes through force feedback. Stem Cells Int. 2016, 2016, 9762959. [CrossRef]

56. Goumans, M.-J.; Valdimarsdottir, G.; Itoh, S.; Lebrin, F.; Larsson, J.; Mummery, C.; Karlsson, S.; Ten Dijke, P. Activin receptor-like kinase (ALK) 1 is an antagonistic mediator of lateral TGF $\beta$ / ALK5 signaling. Mol. Cell 2003, 12, 817-828. [CrossRef]

57. Chen, P.-Y.; Simons, M. Fibroblast growth factor-transforming growth factor beta dialogues, endothelial cell to mesenchymal transition, and atherosclerosis. Curr. Opin. Lipidol. 2018, 29, 397-403. [CrossRef]

58. Hao, Y.-M.; Yuan, H.-Q.; Ren, Z.; Qu, S.-L.; Liu, L.-S.; Yin, K.; Fu, M.; Jiang, Z.-S. Endothelial to mesenchymal transition in atherosclerotic vascular remodeling. Clin. Chim. Acta 2019, 490, 34-38. [CrossRef]

59. Troletti, C.D.; de Goede, P.; Kamermans, A.; de Vries, H.E. Molecular alterations of the blood-brain barrier under inflammatory conditions: The role of endothelial to mesenchymal transition. Biochim. Biophys. Acta Mol. Basis Dis. 2016, 1862, 452-460. [CrossRef] [PubMed]

60. Sacks, D.; Baxter, B.; Campbell, B.C.; Carpenter, J.S.; Cognard, C.; Dippel, D.; Eesa, M.; Fischer, U.; Hausegger, K. Multisociety consensus quality improvement revised consensus statement for endovascular therapy of acute ischemic stroke. Int. J. Stroke 2018, 13, 612-632. [CrossRef]

61. Ma, J.; Sanchez-Duffhues, G.; Goumans, M.-J.; Ten Dijke, P. Tgf- $\beta$-induced endothelial to mesenchymal transition in disease and tissue engineering. Front. Cell Dev. Biol. 2020, 8, 260. [CrossRef]

62. Tarquini, R.; Lazzeri, C.; Pala, L.; Rotella, C.M.; Gensini, G.F. The diabetic cardiomyopathy. Acta Diabetol. 2011, 48, 173-181. [CrossRef]

63. Asbun, J.; Villarreal, F.J. The pathogenesis of myocardial fibrosis in the setting of diabetic cardiomyopathy. J. Am. Coll. Cardiol. 2006, 47, 693-700. [CrossRef]

64. Stern, S.; Behar, S.; Gottlieb, S. Aging and diseases of the heart. Circulation 2003, 108, e99-e101. [CrossRef]

65. Dai, D.-F.; Chen, T.; Johnson, S.C.; Szeto, H.; Rabinovitch, P.S. Cardiac aging: From molecular mechanisms to significance in human health and disease. Antioxid. Redox Signal. 2012, 16, 1492-1526. [CrossRef] [PubMed]

66. Antelmi, I.; De Paula, R.S.; Shinzato, A.R.; Peres, C.A.; Mansur, A.J.; Grupi, C.J. Influence of age, gender, body mass index, and functional capacity on heart rate variability in a cohort of subjects without heart disease. Am. J. Cardiol. 2004, 93, 381-385. [CrossRef] [PubMed]

67. Lakatta, E.G.; Levy, D. Arterial and cardiac aging: Major shareholders in cardiovascular disease enterprises: Part II: The aging heart in health: Links to heart disease. Circulation 2003, 107, 346-354. [CrossRef] [PubMed]

68. Cheitlin, M.D. Cardiovascular physiology—changes with aging. Am. J. Geriatr. Cardiol. 2003, 12, 9-13. [CrossRef] [PubMed] 
69. Goumans, M.-J.; van Zonneveld, A.J.; ten Dijke, P. Transforming growth factor $\beta$-induced endothelial-to-mesenchymal transition: A switch to cardiac fibrosis? Trends Cardiovasc. Med. 2008, 18, 293-298. [CrossRef]

70. Kong, P.; Christia, P.; Frangogiannis, N.G. The pathogenesis of cardiac fibrosis. Cell. Mol. Life Sci. 2014, 71, 549-574. [CrossRef]

71. Pinto, A.R.; Ilinykh, A.; Ivey, M.J.; Kuwabara, J.T.; D’antoni, M.L.; Debuque, R.; Chandran, A.; Wang, L.; Arora, K.; Rosenthal, N.A. Revisiting cardiac cellular composition. Circ. Res. 2016, 118, 400-409. [CrossRef]

72. Abe, K.; Kimura, H. The possible role of hydrogen sulfide as an endogenous neuromodulator. J. Neurosci. 1996, 16, 1066-1071. [CrossRef]

73. Bucci, M.; Papapetropoulos, A.; Vellecco, V.; Zhou, Z.; Zaid, A.; Giannogonas, P.; Cantalupo, A.; Dhayade, S.; Karalis, K.P.; Wang, R. cGMP-dependent protein kinase contributes to hydrogen sulfide-stimulated vasorelaxation. PLoS ONE 2012, 7, e53319. [CrossRef] [PubMed]

74. Vellecco, V.; Mancini, A.; Ianaro, A.; Calderone, V.; Attanasio, C.; Cantalupo, A.; Andria, B.; Savoia, G.; Panza, E.; Di Martino, A. Cystathionine $\beta$-synthase-derived hydrogen sulfide is involved in human malignant hyperthermia. Clin. Sci. 2016, 130, 35-44. [CrossRef] [PubMed]

75. Shibuya, N.; Tanaka, M.; Yoshida, M.; Ogasawara, Y.; Togawa, T.; Ishii, K.; Kimura, H. 3-Mercaptopyruvate sulfurtransferase produces hydrogen sulfide and bound sulfane sulfur in the brain. Antioxid. Redox Signal. 2009, 11, 703-714. [CrossRef] [PubMed]

76. Módis, K.; Asimakopoulou, A.; Coletta, C.; Papapetropoulos, A.; Szabo, C. Oxidative stress suppresses the cellular bioenergetic effect of the 3-mercaptopyruvate sulfurtransferase/hydrogen sulfide pathway. Biochem. Biophys. Res. Commun. 2013, 433, 401-407. [CrossRef]

77. Martelli, A.; Testai, L.; Breschi, M.C.; Blandizzi, C.; Virdis, A.; Taddei, S.; Calderone, V. Hydrogen sulphide: Novel opportunity for drug discovery. Med. Res. Rev. 2012, 32, 1093-1130. [CrossRef]

78. Mitidieri, E.; Gurgone, D.; Caiazzo, E.; Tramontano, T.; Cicala, C.; Sorrentino, R.; d'Emmanuele di Villa Bianca, R. L-cysteine/ cystathionine- $\beta$-synthase-induced relaxation in mouse aorta involves a L-serine/sphingosine-1-phosphate/NO pathway. Br. J. Pharmacol. 2020, 177, 734-744. [CrossRef]

79. Testai, L.; D'Antongiovanni, V.; Piano, I.; Martelli, A.; Citi, V.; Duranti, E.; Virdis, A.; Blandizzi, C.; Gargini, C.; Breschi, M.C. Different patterns of $\mathrm{H} 2 \mathrm{~S} / \mathrm{NO}$ activity and cross-talk in the control of the coronary vascular bed under normotensive or hypertensive conditions. Nitric Oxide 2015, 47, 25-33. [CrossRef]

80. Hosoki, R.; Matsuki, N.; Kimura, H. The possible role of hydrogen sulfide as an endogenous smooth muscle relaxant in synergy with nitric oxide. Biochem. Biophys. Res. Commun. 1997, 237, 527-531. [CrossRef]

81. Fiorucci, S.; Distrutti, E.; Cirino, G.; Wallace, J.L. The emerging roles of hydrogen sulfide in the gastrointestinal tract and liver. Gastroenterology 2006, 131, 259-271. [CrossRef]

82. Zhao, W.; Zhang, J.; Lu, Y.; Wang, R. The vasorelaxant effect of H2S as a novel endogenous gaseous KATP channel opener. EMBO J. 2001, 20, 6008-6016. [CrossRef]

83. Salloum, F.N. Hydrogen sulfide and cardioprotection-Mechanistic insights and clinical translatability. Pharmacol. Ther. 2015, 152, 11-17. [CrossRef] [PubMed]

84. Shibuya, N.; Mikami, Y.; Kimura, Y.; Nagahara, N.; Kimura, H. Vascular endothelium expresses 3-mercaptopyruvate sulfurtransferase and produces hydrogen sulfide. J. Biochem. 2009, 146, 623-626. [CrossRef]

85. Bucci, M.; Papapetropoulos, A.; Vellecco, V.; Zhou, Z.; Pyriochou, A.; Roussos, C.; Roviezzo, F.; Brancaleone, V.; Cirino, G. Hydrogen sulfide is an endogenous inhibitor of phosphodiesterase activity. Arterioscler. Thromb. Vasc. Biol. 2010, 30, $1998-2004$. [CrossRef] [PubMed]

86. Shefa, U.; Kim, M.-S.; Jeong, N.Y.; Jung, J. Antioxidant and cell-signaling functions of hydrogen sulfide in the central nervous system. Oxidative Med. Cell. Longev. 2018, 2018, 1873962. [CrossRef]

87. Citi, V.; Piragine, E.; Testai, L.; Breschi, M.C.; Calderone, V.; Martelli, A. The role of hydrogen sulfide and H2S-donors in myocardial protection against ischemia/reperfusion injury. Curr. Med. Chem. 2018, 25, 4380-4401. [CrossRef]

88. Martelli, A.; Testai, L.; Breschi, M.C.; Lawson, K.; McKay, N.; Miceli, F.; Taglialatela, M.; Calderone, V. Vasorelaxation by hydrogen sulphide involves activation of Kv7 potassium channels. Pharmacol. Res. 2013, 70, 27-34. [CrossRef] [PubMed]

89. Mannelli, L.D.C.; Lucarini, E.; Micheli, L.; Mosca, I.; Ambrosino, P.; Soldovieri, M.V.; Martelli, A.; Testai, L.; Taglialatela, M.; Calderone, V. Effects of natural and synthetic isothiocyanate-based H2S-releasers against chemotherapy-induced neuropathic pain: Role of Kv7 potassium channels. Neuropharmacology 2017, 121, 49-59. [CrossRef] [PubMed]

90. Ahmed, A. Molecular mechanisms and therapeutic implications of the carbon monoxide/hmox1 and the hydrogen sulfide/CSE pathways in the prevention of pre-eclampsia and fetal growth restriction. Pregnancy Hypertens. Int. J. Women's Cardiovasc. Health 2014, 4, 243-244. [CrossRef] [PubMed]

91. Mok, Y.Y.P.; Mohammed Atan, M.S.B.; Ping, C.Y.; Jing, W.Z.; Bhatia, M.; Moochhala, S.; Moore, P.K. Role of hydrogen sulphide in haemorrhagic shock in the rat: Protective effect of inhibitors of hydrogen sulphide biosynthesis. Br. J. Pharmacol. 2004, 143, 881-889. [CrossRef] [PubMed]

92. Whiteman, M.; Li, L.; Rose, P.; Tan, C.-H.; Parkinson, D.B.; Moore, P.K. The effect of hydrogen sulfide donors on lipopolysaccharideinduced formation of inflammatory mediators in macrophages. Antioxid. Redox Signal. 2010, 12, 1147-1154. [CrossRef] [PubMed]

93. Zanardo, R.C.; Brancaleone, V.; Distrutti, E.; Fiorucci, S.; Cirino, G.; Wallace, J.L.; Zanardo, R.C.; Brancaleone, V.; Distrutti, E.; Fiorucci, S. Hydrogen sulfide is an endogenous modulator of leukocyte-mediated inflammation. FASEB J. 2006, 20, 2118-2120. [CrossRef]

94. Brancaleone, V.; Mitidieri, E.; Flower, R.J.; Cirino, G.; Perretti, M. Annexin A1 mediates hydrogen sulfide properties in the control of inflammation. J. Pharmacol. Exp. Ther. 2014, 351, 96-104. [CrossRef] [PubMed] 
95. Citi, V.; Corvino, A.; Fiorino, F.; Frecentese, F.; Magli, E.; Perissutti, E.; Santagada, V.; Brogi, S.; Flori, L.; Gorica, E. Structure-activity relationships study of isothiocyanates for $\mathrm{H} 2 \mathrm{~S}$ releasing properties: 3-Pyridyl-isothiocyanate as a new promising cardioprotective agent. J. Adv. Res. 2020, 27, 41-53. [CrossRef]

96. Testai, L.; Marino, A.; Piano, I.; Brancaleone, V.; Tomita, K.; Mannelli, L.D.C.; Martelli, A.; Citi, V.; Breschi, M.C.; Levi, R. The novel H2S-donor 4-carboxyphenyl isothiocyanate promotes cardioprotective effects against ischemia/reperfusion injury through activation of mitoKATP channels and reduction of oxidative stress. Pharmacol. Res. 2016, 113, 290-299. [CrossRef]

97. Kimura, Y.; Goto, Y.-I.; Kimura, H. Hydrogen sulfide increases glutathione production and suppresses oxidative stress in mitochondria. Antioxid. Redox Signal. 2010, 12, 1-13. [CrossRef]

98. Mustafa, A.K.; Gadalla, M.M.; Sen, N.; Kim, S.; Mu, W.; Gazi, S.K.; Barrow, R.K.; Yang, G.; Wang, R.; Snyder, S.H. H2S signals through protein S-sulfhydration. Sci. Signal. 2009, 2, ra72. [CrossRef]

99. Paul, B.D.; Snyder, S.H. H 2 S signalling through protein sulfhydration and beyond. Nat. Rev. Mol. Cell Biol. 2012, 13, 499-507. [CrossRef]

100. Altaany, Z.; Ju, Y.; Yang, G.; Wang, R. The coordination of S-sulfhydration, S-nitrosylation, and phosphorylation of endothelial nitric oxide synthase by hydrogen sulfide. Sci. Signal. 2014, 7, ra87. [CrossRef]

101. Marutani, E.; Yamada, M.; Ida, T.; Tokuda, K.; Ikeda, K.; Kai, S.; Shirozu, K.; Hayashida, K.; Kosugi, S.; Hanaoka, K. Thiosulfate mediates cytoprotective effects of hydrogen sulfide against neuronal ischemia. J. Am. Heart Assoc. 2015, 4, e002125. [CrossRef]

102. Sen, N.; Paul, B.D.; Gadalla, M.M.; Mustafa, A.K.; Sen, T.; Xu, R.; Kim, S.; Snyder, S.H. Hydrogen sulfide-linked sulfhydration of NF-kB mediates its antiapoptotic actions. Mol. Cell 2012, 45, 13-24. [CrossRef]

103. Cai, J.; Shi, X.; Wang, H.; Fan, J.; Feng, Y.; Lin, X.; Yang, J.; Cui, Q.; Tang, C.; Xu, G. Cystathionine $\gamma$ lyase-hydrogen sulfide increases peroxisome proliferator-activated receptor $\gamma$ activity by sulfhydration at $\mathrm{C} 139$ site thereby promoting glucose uptake and lipid storage in adipocytes. Biochim. Biophys. Acta Mol. Cell Biol. Lipids 2016, 1861, 419-429. [CrossRef]

104. Zhou, X.; An, G.; Lu, X. Hydrogen sulfide attenuates the development of diabetic cardiomyopathy. Clin. Sci. 2015, 128, 325-335. [CrossRef] [PubMed]

105. Cao, X.; Ding, L.; Xie, Z.-Z.; Yang, Y.; Whiteman, M.; Moore, P.K.; Bian, J.-S. A review of hydrogen sulfide synthesis, metabolism, and measurement: Is modulation of hydrogen sulfide a novel therapeutic for cancer? Antioxid. Redox Signal. 2019, 31, 1-38. [CrossRef]

106. Insko, M.A.; Deckwerth, T.L.; Hill, P.; Toombs, C.F.; Szabo, C. Detection of exhaled hydrogen sulphide gas in rats exposed to intravenous sodium sulphide. Br. J. Pharmacol. 2009, 157, 944-951. [CrossRef] [PubMed]

107. Toombs, C.F.; Insko, M.A.; Wintner, E.A.; Deckwerth, T.L.; Usansky, H.; Jamil, K.; Goldstein, B.; Cooreman, M.; Szabo, C. Detection of exhaled hydrogen sulphide gas in healthy human volunteers during intravenous administration of sodium sulphide. Br. J. Clin. Pharmacol. 2010, 69, 626-636. [CrossRef] [PubMed]

108. Mallat, Z.; Gojova, A.; Marchiol-Fournigault, C.; Esposito, B.; Kamaté, C.; Merval, R.; Fradelizi, D.; Tedgui, A. Inhibition of transforming growth factor- $\beta$ signaling accelerates atherosclerosis and induces an unstable plaque phenotype in mice. Circ. Res. 2001, 89, 930-934. [CrossRef] [PubMed]

109. Lu, X.; Wang, S.; Feng, S.; Li, H. CSE/H 2 S system alleviates uremic accelerated atherosclerosis by regulating TGF- $\beta /$ Smad3 pathway in 5/6 nephrectomy ApoE-/-mice. BMC Nephrol. 2020, 21, 1-9. [CrossRef]

110. Mani, S.; Untereiner, A.; Wu, L.; Wang, R. Hydrogen sulfide and the pathogenesis of atherosclerosis. Antioxid. Redox Signal. 2014, 20, 805-817. [CrossRef]

111. Mani, S.; Li, H.; Untereiner, A.; Wu, L.; Yang, G.; Austin, R.C.; Dickhout, J.G.; Lhoták, Š.; Meng, Q.H.; Wang, R. Decreased endogenous production of hydrogen sulfide accelerates atherosclerosis. Circulation 2013, 127, 2523-2534. [CrossRef] [PubMed]

112. Kavurma, M.M.; Rayner, K.J.; Karunakaran, D. The walking dead: Macrophage inflammation and death in atherosclerosis. Curr. Opin. Lipidol. 2017, 28, 91. [CrossRef] [PubMed]

113. Sun, H.-J.; Wu, Z.-Y.; Nie, X.-W.; Bian, J.-S. Role of endothelial dysfunction in cardiovascular diseases: The link between inflammation and hydrogen sulfide. Front. Pharmacol. 2020, 10, 1568. [CrossRef]

114. Meng, G.; Ma, Y.; Xie, L.; Ferro, A.; Ji, Y. Emerging role of hydrogen sulfide in hypertension and related cardiovascular diseases. Br. J. Pharmacol. 2015, 172, 5501-5511. [CrossRef] [PubMed]

115. Snijder, P.; Frenay, A.; De Boer, R.; Pasch, A.; Hillebrands, J.; Leuvenink, H.; Van Goor, H. Exogenous administration of thiosulfate, a donor of hydrogen sulfide, attenuates angiotensin II-induced hypertensive heart disease in rats. Br. J. Pharmacol. 2015, 172, 1494-1504. [CrossRef]

116. Laggner, H.; Hermann, M.; Esterbauer, H.; Muellner, M.K.; Exner, M.; Gmeiner, B.M.; Kapiotis, S. The novel gaseous vasorelaxant hydrogen sulfide inhibits angiotensin-converting enzyme activity of endothelial cells. J. Hypertens. 2007, 25, 2100-2104. [CrossRef]

117. Wu, T.; Li, H.; Wu, B.; Zhang, L.; Wu, S.-W.; Wang, J.-n.; Zhang, Y.-e. Hydrogen sulfide reduces recruitment of CD11b + DG Gr-1 + DG cells in mice with myocardial infarction. Cell Transplant. 2017, 26, 753-764. [CrossRef]

118. Gerő, D.; Torregrossa, R.; Perry, A.; Waters, A.; Le-Trionnaire, S.; Whatmore, J.L.; Wood, M.; Whiteman, M. The novel mitochondriatargeted hydrogen sulfide (H2S) donors AP123 and AP39 protect against hyperglycemic injury in microvascular endothelial cells in vitro. Pharmacol. Res. 2016, 113, 186-198. [CrossRef]

119. Jin, S.; Teng, X.; Xiao, L.; Xue, H.; Guo, Q.; Duan, X.; Chen, Y.; Wu, Y. Hydrogen sulfide ameliorated L-NAME-induced hypertensive heart disease by the Akt/eNOS/NO pathway. Exp. Biol. Med. 2017, 242, 1831-1841. [CrossRef]

120. Zhang, H.; Bai, Z.; Zhu, L.; Liang, Y.; Fan, X.; Li, J.; Wen, H.; Shi, T.; Zhao, Q.; Wang, Z. Hydrogen sulfide donors: Therapeutic potential in anti-atherosclerosis. Eur. J. Med. Chem. 2020, 205, 112665. [CrossRef] 
121. WU, S.y.; PAN, C.s.; Geng, B.; Zhao, J.; Yu, F.; PANG, Y.z.; TANG, C.s.; QI, Y.f. Hydrogen sulfide ameliorates vascular calcification induced by vitamin D3 plus nicotine in rats 1. Acta Pharmacol. Sin. 2006, 27, 299-306. [CrossRef] [PubMed]

122. Meng, Q.H.; Yang, G.; Yang, W.; Jiang, B.; Wu, L.; Wang, R. Protective effect of hydrogen sulfide on balloon injury-induced neointima hyperplasia in rat carotid arteries. Am. J. Pathol. 2007, 170, 1406-1414. [CrossRef] [PubMed]

123. Citi, V.; Martelli, A.; Gorica, E.; Brogi, S.; Testai, L.; Calderone, V. Role of hydrogen sulfide in endothelial dysfunction: Pathophysiology and therapeutic approaches. J. Adv. Res. 2020, 27, 99-113. [CrossRef]

124. McCully, K.S. Vascular pathology of homocysteinemia: Implications for the pathogenesis of arteriosclerosis. Am. J. Pathol. 1969, 56,111 .

125. Tyagi, S.C. Homocyst (e) ine and heart disease: Pathophysiology of extracellular matrix. Clin. Exp. Hypertens. 1999, 21, 181-198. [CrossRef]

126. Boers, G.H.; Smals, A.G.; Trijbels, F.J.; Fowler, B.; Bakkeren, J.A.; Schoonderwaldt, H.C.; Kleijer, W.J.; Kloppenborg, P.W. Heterozygosity for homocystinuria in premature peripheral and cerebral occlusive arterial disease. New Engl. J. Med. 1985, 313, 709-715. [CrossRef]

127. Mujumdar, V.S.; Hayden, M.R.; Tyagi, S.C. Homocyst (e) ine induces calcium second messenger in vascular smooth muscle cells. J. Cell. Physiol. 2000, 183, 28-36. [CrossRef]

128. Tyagi, S.C.; Smiley, L.M.; Mujumdar, V.S. Reduction-oxidation (Redox) and vascular tissue level of homocyst (e) ine in human coronary atherosclerotic lesions and role in extracellular matrix remodeling and vascular tone. Mol. Cell. Biochem. 1998, 181, 107-116. [CrossRef] [PubMed]

129. Sen, U.; Basu, P.; Abe, O.A.; Givvimani, S.; Tyagi, N.; Metreveli, N.; Shah, K.S.; Passmore, J.C.; Tyagi, S.C. Hydrogen sulfide ameliorates hyperhomocysteinemia-associated chronic renal failure. Am. J. Physiol. Ren. Physiol. 2009, 297, F410-F419. [CrossRef]

130. Yao, K. Effects of several unusual sulfur-containing amino acids on rat liver cystathionine-gamma-lyase. Physiol. Chem. Phys. 1975, 7, 401-408. [PubMed]

131. Chang, L.; Geng, B.; Yu, F.; Zhao, J.; Jiang, H.; Du, J.; Tang, C. Hydrogen sulfide inhibits myocardial injury induced by homocysteine in rats. Amino Acids 2008, 34, 573-585. [CrossRef]

132. Sen, U.; Herrmann, M.; Herrmann, W.; Tyagi, S.C. Synergism between AT1 receptor and hyperhomocysteinemia during vascular remodeling. Clin. Chem. Lab. Med. 2007, 45, 1771-1776. [CrossRef]

133. Sen, U.; Mishra, P.K.; Tyagi, N.; Tyagi, S.C. Homocysteine to hydrogen sulfide or hypertension. Cell Biochem. Biophys. 2010, 57, 49-58. [CrossRef]

134. Hongfang, J.; Bailin, C.; Bin, Z.; Chunyu, Z.; Xinmin, L.; Weijin, Z.; Ying, S.; Chaoshu, T.; Junbao, D. Effects of hydrogen sulfide on hypoxic pulmonary vascular structural remodeling. Life Sci. 2006, 78, 1299-1309. [CrossRef]

135. Talman, V.; Ruskoaho, H. Cardiac fibrosis in myocardial infarction-From repair and remodeling to regeneration. Cell Tissue Res. 2016, 365, 563-581. [CrossRef]

136. Shen, Y.; Shen, Z.; Miao, L.; Xin, X.; Lin, S.; Zhu, Y.; Guo, W.; Zhu, Y.Z. miRNA-30 family inhibition protects against cardiac ischemic injury by regulating cystathionine- $\gamma$-lyase expression. Antioxid. Redox Signal. 2015, 22, 224-240. [CrossRef] [PubMed]

137. Jiang, H.; Wu, H.; Li, Z.; Geng, B.; Tang, C. Changes of the new gaseous transmitter H2S in patients with coronary heart disease. Di 1 Jun Yi Da Xue Xue Bao Acad. J. First Med Coll. PLA 2005, 25, 951-954.

138. Testai, L.; Barrese, V.; Soldovieri, M.V.; Ambrosino, P.; Martelli, A.; Vinciguerra, I.; Miceli, F.; Greenwood, I.A.; Curtis, M.J.; Breschi, M.C. Expression and function of Kv7. 4 channels in rat cardiac mitochondria: Possible targets for cardioprotection. Cardiovasc. Res. 2016, 110, 40-50. [CrossRef]

139. Shimizu, Y.; Nicholson, C.K.; Lambert, J.P.; Barr, L.A.; Kuek, N.; Herszenhaut, D.; Tan, L.; Murohara, T.; Hansen, J.M.; Husain, A. Sodium sulfide attenuates ischemic-induced heart failure by enhancing proteasomal function in an Nrf2-dependent manner. Circ. Heart Fail. 2016, 9, e002368. [CrossRef]

140. Xie, L.; Gu, Y.; Wen, M.; Zhao, S.; Wang, W.; Ma, Y.; Meng, G.; Han, Y.; Wang, Y.; Liu, G. Hydrogen sulfide induces Keap1 S-sulfhydration and suppresses diabetes-accelerated atherosclerosis via Nrf2 activation. Diabetes 2016, 65, 3171-3184. [CrossRef]

141. Tsai, C.-Y.; Wang, C.-C.; Lai, T.-Y.; Tsu, H.-N.; Wang, C.-H.; Liang, H.-Y.; Kuo, W.-W. Antioxidant effects of diallyl trisulfide on high glucose-induced apoptosis are mediated by the PI3K/Akt-dependent activation of Nrf2 in cardiomyocytes. Int. J. Cardiol. 2013, 168, 1286-1297. [CrossRef]

142. Rodriguez, A.M.; Yin, V.P. Emerging roles for immune cells and microRNAs in modulating the response to cardiac injury. J. Cardiovasc. Dev. Dis. 2019, 6, 5. [CrossRef]

143. Toldo, S.; Das, A.; Mezzaroma, E.; Chau, V.Q.; Marchetti, C.; Durrant, D.; Samidurai, A.; Van Tassell, B.W.; Yin, C.; Ockaili, R.A. Induction of microRNA-21 with exogenous hydrogen sulfide attenuates myocardial ischemic and inflammatory injury in mice. Circ. Cardiovasc. Genet. 2014, 7, 311-320. [CrossRef]

144. Li, H.; Zhang, C.; Sun, W.; Li, L.; Wu, B.; Bai, S.; Li, H.; Zhong, X.; Wang, R.; Wu, L. Exogenous hydrogen sulfide restores cardioprotection of ischemic post-conditioning via inhibition of $\mathrm{MPTP}$ opening in the aging cardiomyocytes. Cell Biosci. 2015, 5, 1-17. [CrossRef]

145. Chatzianastasiou, A.; Bibli, S.-I.; Andreadou, I.; Efentakis, P.; Kaludercic, N.; Wood, M.E.; Whiteman, M.; Di Lisa, F.; Daiber, A.; Manolopoulos, V.G. Cardioprotection by H2S donors: Nitric oxide-dependent and-independent mechanisms. J. Pharmacol. Exp. Ther. 2016, 358, 431-440. [CrossRef] 
146. Karwi, Q.G.; Bornbaum, J.; Boengler, K.; Torregrossa, R.; Whiteman, M.; Wood, M.E.; Schulz, R.; Baxter, G.F. AP39, a mitochondriatargeting hydrogen sulfide (H2S) donor, protects against myocardial reperfusion injury independently of salvage kinase signalling. Br. J. Pharmacol. 2017, 174, 287-301. [CrossRef]

147. Elrod, J.W.; Calvert, J.W.; Morrison, J.; Doeller, J.E.; Kraus, D.W.; Tao, L.; Jiao, X.; Scalia, R.; Kiss, L.; Szabo, C. Hydrogen sulfide attenuates myocardial ischemia-reperfusion injury by preservation of mitochondrial function. Proc. Natl. Acad. Sci. USA 2007, 104, 15560-15565. [CrossRef] [PubMed]

148. Geng, B.; Chang, L.; Pan, C.; Qi, Y.; Zhao, J.; Pang, Y.; Du, J.; Tang, C. Endogenous hydrogen sulfide regulation of myocardial injury induced by isoproterenol. Biochem. Biophys. Res. Commun. 2004, 318, 756-763. [CrossRef]

149. Meng, G.; Wang, J.; Xiao, Y.; Bai, W.; Xie, L.; Shan, L.; Moore, P.K.; Ji, Y. GYY4137 protects against myocardial ischemia and reperfusion injury by attenuating oxidative stress and apoptosis in rats. J. Biomed. Res. 2015, $29,203$.

150. Meng, G.; Zhu, J.; Xiao, Y.; Huang, Z.; Zhang, Y.; Tang, X.; Xie, L.; Chen, Y.; Shao, Y.; Ferro, A. Hydrogen sulfide donor GYY4137 protects against myocardial fibrosis. Oxidative Med. Cell. Longev. 2015, 2015. [CrossRef]

151. Zhu, C.; Su, Y.; Juriasingani, S.; Zheng, H.; Veramkovich, V.; Jiang, J.; Sener, A.; Whiteman, M.; Lacefield, J.; Nagpal, D Supplementing preservation solution with mitochondria-targeted H2S donor AP 39 protects cardiac grafts from prolonged cold ischemia-reperfusion injury in heart transplantation. Am. J. Transplant. 2019, 19, 3139-3148. [CrossRef] [PubMed]

152. Hua, W.; Chen, Q.; Gong, F.; Xie, C.; Zhou, S.; Gao, L. Cardioprotection of H2S by downregulating iNOS and upregulating HO-1 expression in mice with CVB3-induced myocarditis. Life Sci. 2013, 93, 949-954. [CrossRef]

153. Ge, N.; Liu, C.; Li, G.; Xie, L.; Zhang, Q.; Li, L.; Hao, N.; Zhang, J. Hydrosulfide attenuates acute myocardial ischemic injury through the glycogen synthase kinase-3 $\beta / \beta$-catenin signaling pathway. Int. J. Mol. Med. 2016, 37, 1281-1289. [CrossRef]

154. Bibli, S.-I.; Andreadou, I.; Chatzianastasiou, A.; Tzimas, C.; Sanoudou, D.; Kranias, E.; Brouckaert, P.; Coletta, C.; Szabo, C.; Kremastinos, D.T. Cardioprotection by H2S engages a cGMP-dependent protein kinase G/phospholamban pathway. Cardiovasc. Res. 2015, 106, 432-442. [CrossRef] [PubMed]

155. Qipshidze, N.; Metreveli, N.; Mishra, P.K.; Lominadze, D.; Tyagi, S.C. Hydrogen sulfide mitigates cardiac remodeling during myocardial infarction via improvement of angiogenesis. Int. J. Biol. Sci. 2012, 8, 430. [CrossRef]

156. Chen, J.; Gao, J.; Sun, W.; Li, L.; Wang, Y.; Bai, S.; Li, X.; Wang, R.; Wu, L.; Li, H. Involvement of exogenous H2S in recovery of cardioprotection from ischemic post-conditioning via increase of autophagy in the aged hearts. Int. J. Cardiol. 2016, 220, 681-692. [CrossRef]

157. Kang, S.C.; Sohn, E.-H.; Lee, S.R. Hydrogen sulfide as a potential alternative for the treatment of myocardial fibrosis. Oxidative Med. Cell. Longev. 2020, 2020, 4105382. [CrossRef]

158. Lilyanna, S.; Peh, M.T.; Liew, O.W.; Wang, P.; Moore, P.K.; Richards, A.M.; Martinez, E.C. GYY4137 attenuates remodeling, preserves cardiac function and modulates the natriuretic peptide response to ischemia. J. Mol. Cell. Cardiol. 2015, 87, 27-37. [CrossRef] [PubMed]

159. Polhemus, D.J.; Kondo, K.; Bhushan, S.; Bir, S.C.; Kevil, C.G.; Murohara, T.; Lefer, D.J.; Calvert, J.W. Hydrogen sulfide attenuates cardiac dysfunction after heart failure via induction of angiogenesis. Circ. Heart Fail. 2013, 6, 1077-1086. [CrossRef]

160. Barr, L.A.; Shimizu, Y.; Lambert, J.P.; Nicholson, C.K.; Calvert, J.W. Hydrogen sulfide attenuates high fat diet-induced cardiac dysfunction via the suppression of endoplasmic reticulum stress. Nitric Oxide 2015, 46, 145-156. [CrossRef] [PubMed]

161. Polhemus, D.J.; Li, Z.; Pattillo, C.B.; Gojon Sr, G.; Gojon, G., Jr.; Giordano, T.; Krum, H. A novel hydrogen sulfide prodrug, SG 1002, promotes hydrogen sulfide and nitric oxide bioavailability in heart failure patients. Cardiovasc. Ther. 2015, 33, 216-226. [CrossRef]

162. Pappachan, J.M.; Varughese, G.I.; Sriraman, R.; Arunagirinathan, G. Diabetic cardiomyopathy: Pathophysiology, diagnostic evaluation and management. World J. Diabetes 2013, 4, 177. [CrossRef]

163. Jain, S.K.; Bull, R.; Rains, J.L.; Bass, P.F.; Levine, S.N.; Reddy, S.; McVie, R.; Bocchini, J.A., Jr. Low Levels of Hydrogen Sulfide in the Blood of Diabetes Patients and Streptozotocin-Treated rats Causes Vascular Inflammation? Mary Ann Liebert Inc.: New Rochelle, NY, USA, 2010.

164. Liu, M.; Li, Y.; Liang, B.; Li, Z.; Jiang, Z.; Chu, C.; Yang, J. Hydrogen sulfide attenuates myocardial fibrosis in diabetic rats through the JAK/STAT signaling pathway. Int. J. Mol. Med. 2018, 41, 1867-1876. [CrossRef]

165. Jin, S.; Pu, S.-X.; Hou, C.-L.; Ma, F.-F.; Li, N.; Li, X.-H.; Tan, B.; Tao, B.-B.; Wang, M.-J.; Zhu, Y.-C. Cardiac H2S generation is reduced in ageing diabetic mice. Oxidative Med. Cell. Longev. 2015, 2015, 758358. [CrossRef] [PubMed]

166. Xiao, T.; Luo, J.; Wu, Z.; Li, F.; Zeng, O.; Yang, J. Effects of hydrogen sulfide on myocardial fibrosis and PI3K/AKT1-regulated autophagy in diabetic rats. Mol. Med. Rep. 2016, 13, 1765-1773. [CrossRef] [PubMed]

167. Long, J.; Liu, M.; Liu, S.; Tang, F.; Tan, W.; Xiao, T.; Chu, C.; Yang, J. H2S attenuates the myocardial fibrosis in diabetic rats through modulating PKC-ERK1/2MAPK signaling pathway. Technol. Health Care 2019, 27, 307-316. [CrossRef] [PubMed]

168. Xiao, T.; Zeng, O.; Luo, J.; Wu, Z.; Li, F.; Yang, J. Effects of hydrogen sulfide on myocardial fibrosis in diabetic rats: Changes in matrix metalloproteinases parameters. Bio-med. Mater. Eng. 2015, 26, S2033-S2039. [CrossRef] [PubMed]

169. Yang, R.; Jia, Q.; Ma, S.F.; Wang, Y.; Mehmood, S.; Chen, Y. Exogenous H2S mitigates myocardial fibrosis in diabetic rats through suppression of the canonical Wnt pathway. Int. J. Mol. Med. 2019, 44, 549-558. [CrossRef]

170. Ye, P.; Gu, Y.; Zhu, Y.R.; Chao, Y.L.; Kong, X.Q.; Luo, J.; Ren, X.M.; Zuo, G.F.; Zhang, D.M.; Chen, S.L. Exogenous hydrogen sulfide attenuates the development of diabetic cardiomyopathy via the FoxO1 pathway. J. Cell. Physiol. 2018, 233, 9786-9798. [CrossRef] [PubMed] 
171. Shimizu, Y.; Polavarapu, R.; Eskla, K.-L.; Nicholson, C.K.; Koczor, C.A.; Wang, R.; Lewis, W.; Shiva, S.; Lefer, D.J.; Calvert, J.W. Hydrogen sulfide regulates cardiac mitochondrial biogenesis via the activation of AMPK. J. Mol. Cell. Cardiol. 2018, 116, 29-40. [CrossRef] [PubMed]

172. Liang, B.; Xiao, T.; Long, J.; Liu, M.; Li, Z.; Liu, S.; Yang, J. Hydrogen sulfide alleviates myocardial fibrosis in mice with alcoholic cardiomyopathy by downregulating autophagy. Int. J. Mol. Med. 2017, 40, 1781-1791. [CrossRef] [PubMed]

173. Liu, M.; Li, Z.; Liang, B.; Li, L.; Liu, S.; Tan, W.; Long, J.; Tang, F.; Chu, C.; Yang, J. Hydrogen sulfide ameliorates rat myocardial fibrosis induced by thyroxine through PI3K/AKT signaling pathway. Endocr. J. 2018, EJ17-0445. [CrossRef]

174. Fang, L.; Li, H.; Tang, C.; Geng, B.; Qi, Y.; Liu, X. Hydrogen sulfide attenuates the pathogenesis of pulmonary fibrosis induced by bleomycin in rats. Can. J. Physiol. Pharmacol. 2009, 87, 531-538. [CrossRef] [PubMed]

175. Fang, L.-P.; Lin, Q.; Tang, C.-S.; Liu, X.-M. Hydrogen sulfide attenuates epithelial-mesenchymal transition of human alveolar epithelial cells. Pharmacol. Res. 2010, 61, 298-305. [CrossRef]

176. Bai, Y.W.; Ye, M.J.; Yang, D.L.; Yu, M.P.; Zhou, C.F.; Shen, T. Hydrogen sulfide attenuates paraquat-induced epithelial-mesenchymal transition of human alveolar epithelial cells through regulating transforming growth factor- $\beta 1 / \mathrm{Smad} 2 / 3$ signaling pathway. J. Appl. Toxicol. 2019, 39, 432-440. [CrossRef] [PubMed]

177. Liao, C.-C.; Chen, Y.-H.; Lin, F.; Qi, Y.-F. Hydrogen sulfide inhibits transforming growth factor beta-1 induced bronchial epithelial-mesenchymal transition. Chin. Med. J. 2015, 128, 3247. [CrossRef]

178. Cheng, S.; Lu, Y.; Li, Y.; Gao, L.; Shen, H.; Song, K. Hydrogen sulfide inhibits epithelial-mesenchymal transition in peritoneal mesothelial cells. Sci. Rep. 2018, 8, 1-7. [CrossRef]

179. Ying, R.; Wang, X.-Q.; Yang, Y.; Gu, Z.-J.; Mai, J.-T.; Qiu, Q.; Chen, Y.-X.; Wang, J.-F. Hydrogen sulfide suppresses endoplasmic reticulum stress-induced endothelial-to-mesenchymal transition through Src pathway. Life Sci. 2016, 144, $208-217$. [CrossRef] [PubMed]

180. Zhang, H.; Lin, Y.; Ma, Y.; Zhang, J.; Wang, C.; Zhang, H. Protective effect of hydrogen sulfide on monocrotaline-induced pulmonary arterial hypertension via inhibition of the endothelial mesenchymal transition. Int. J. Mol. Med. 2019, 44, 2091-2102. [CrossRef]

181. Tran, B.H.; Yu, Y.; Chang, L.; Tan, B.; Jia, W.; Xiong, Y.; Dai, T.; Zhong, R.; Zhang, W.; Le, V.M. A novel liposomal S-propargylcysteine: A sustained release of hydrogen sulfide reducing myocardial fibrosis via TGF- $\beta 1 /$ Smad pathway. Int. J. Nanomed. 2019, 14, 10061. [CrossRef] 